\title{
Teknik Gelişmeler Perspektifinde Başlangıcından Post- Fotoğrafa Fotojurnalizmde Gerçekliğin Temsiline Olan Yaklaşımlar
}

\author{
Approaches to the Representation of Reality in Photojournalism from The \\ Beginning to Post Photography within The Perspective of Technical \\ Developments
}

\section{Onur TATAR}

Dr. Öğr. Gör., Aydın Adnan Menderes Üniversitesi İletişim Fakültesi Radyo Televizyon ve Sinema Bölümü email: onurtatar84@gmail.com (DORCID ID: https://orcid.org/0000-0003-1995-160X

iThenticate' Bu makale bilimsel etik ve kurallara uygun hazırlanmış ve intihal incelemesinden geçirilmiş̧tir.

Atıf (APA 6)/To cite this article

Tatar, O. (2020). Teknik gelişmeler perspektifinde başlangıcından post-fotoğrafa fotojurnalizmde gerçekliğin temsiline olan yaklaşımlar. Atatürk Üniversitesi Güzel Sanatlar Enstitüsü Dergisi, 26(44), 229-245. doi: https://doi.org/10.35247/ataunigsed.670867

Makale Gönderim Tarihi/Received: 06/01/2020

Makale Kabul Tarihi/Accepted: 17/03/2020

Makale Yayın Tarihi/Published: 19/03/2020

Review Article / Derleme Makalesi

Öz

Dış dünyaya ait gerçekliği olduğu gibi yansıtma özelliğine sahip olan fotoğraf, icat olduktan sonra toplumsal olayları belgelemek amacıyla kullanılmaya başlanmıştır. $\mathrm{Bu}$ amaç doğrultusunda üretilen çalışmalar, basın teknolojilerinde yaşanan gelişmelerle birlikte yazılı basında yer almasıyla fotoğrafta yeni bir alan ortaya çıkmaktadır. Fotojurnalizm olarak adlandırılan bu alan, haber metninin görseller kullanılarak temellendirilmesine dayanmaktadır ve fotoğrafın doğası itibariyle, nesnel gerçeklikle kurduğu derin bağla yakinen ilişkilidir. Diğer yandan fotoğraf tekniğinde yaşanan teknolojik gelișme ve dönüșümler, fotoğrafçıların objektiflerini yönelttikleri konuları farklı yaklassımlarla cekmelerini sağlamaktadır. $\mathrm{Bu}$ yaklaşımlar, fotojurnalist calışmaların içeriğinde taşıdı ğı gerceklik temsilini etkilemektedir. $\mathrm{Bu}$ bağlamda çalışmada; fotoğrafta yaşanan teknolojik gelişmelerin, fotojurnalist çalıșmalarda yansitılan olayların gerçeklik temsillerine olan yaklaşımlarını ortaya konulması amaçlanmaktadır. Amaca yönelik örneklem yoluyla belirlenmiş örnekler betimsel yöntem ile incelenmektedir.

Anahtar Kelime: Fotoğraf, Fotojurnalizm, Gerçeklik, PostFotoğraf, Post-Fotojurnalizm

\begin{abstract}
Photography, which has the feature of reflecting the reality of the outside world as it is, has been used to document the social events after it was invented. A new field of photography has been emerged with the artworks produced for this purpose take place in the press. This field, called photojournalism, is based on the creation of news text with photographs, and in its nature is closely related to its deep connection with objective reality. On the other hand, the technological developments and transformations in the photographic technique have been allowed photographers to capture the subjects they are aiming at with different approaches. These approaches affect the representation of reality in photojournalist artworks. Thus, in the study; it is aimed to reveal the approaches of technological developments in photography to reality representations of events reflected in photojournalistic artworks. Samples determined through purposeful sampling are examined by descriptive method.
\end{abstract}

Keywords: Photography, Photojournalism, Reality, PostPhotography, Post-Photojournalism

\section{Giris}

Fotoğrafın; 1839 yılında Fransız Bilimler Akademisi'nce kamuoyuna duyurulmasıyla başta ticari ve sanatsal birçok alanda faaliyet göstermeye başlayan ve dünyayı derinden etkileyen bir imaj üretim yöntemi olmasında, kuşkusuz ki dış dünyaya ait gerçekliği kusursuz șekilde yansıtıyor oluşu bulunmaktadır. Fotoğrafik imajın doğasını oluşturan bu özellik, onu diğer sanatsal imaj üretim yöntemlerinden ayırmaktadır. Farklı bir deyişle fotoğrafik imaj, içerisinde bulundurduğu nesne ya da olguları nesnel gerçekliğiyle temsil etmektedir.

Resim gibi sanatçının el becerisine dayalı ve sübjektif gerçekliği yansıtan imaj üretim yöntemlerine nazaran gerçekliği nesnel şekilde yansıtan fotoğraf, bu özelliğiyle kamuoyunu bilgilendirme amacıyla kullanılan bir araç haline gelmiştir. Böylelikle icadından itibaren fotoğraf, belgesel amaçlı, sosyolojik olguları ortaya koymak adına ya da haber aktarımı için kullanılmaktadır. Fotoğrafın gerçekliği nesnel şekilde yansıtma özelliğinden faydalanan diğer bir alan da fotojurnalizmdir.

Haber anlatısının görselleştirilerek hikâyeleştirilmesi anlamına gelen fotojurnalizm, kamuoyunu bilgilendirme amacını taşımaktadır. Fotojurnalizm, haber niteliği taşıyan olayları konu edinmesi açısından gazetecilik ve basın fotoğrafçılığıyla yakından alakalıdır. Buna karşın fotojurnalist çalışmaların, kendilerinin haber niteliği taşıması ve estetik niteliğe sahip olması basın fotoğrafçılığından ayrılmasını sağlamaktadır. 
Bununla birlikte, fotoğraf tekniğinde yaşanan teknolojik değişim ya da dönüşümler haber niteliği taşıyan olayları nesnel gerçeklik çerçevesinde ele alan fotojurnalizmi etkileyerek, fotoğrafçıların konuya olan yaklaşımlarını değiştirmektedir. Dönemsel olarak farklı üslupların ortaya çıkmasına olanak tanıyan bu yaklaşımlar, fotojurnalizmde olay ya da olgulara dair gerçeklik temsillerini de etkilemektedir. Kişisel bakış açısının ön planda tutulduğu fotojurnalizm, genellikle seri fotoğraflardan oluşan ve uzun soluklu sürdürülen bir yaklaşımdır. Diğer yandan bu yaklaşımla oluşturulan bir hikâyenin; durum saptayan, basın ilkelerine bağlı, tarafsız ve etik değerlere sahip olması beklenmektedir. Bu yönüyle fotojurnalizm, fotoğrafın konu edindiği olayları nesnel gerçeklik perspektifinde yansıtma özelliğine temelden bağlıdır. Diğer yandan fotoğraf tekniğinde yaşanan teknik gelişme ve dönüşümler, fotojurnalist çalışmaların temsil ettiği gerçekliğin farklı yaklaşımlar içerisinde aktarılmasına olanak tanımaktadır. $\mathrm{Bu}$ bağlamda çalışmada fotoğraf tekniğinde yaşanan teknolojik gelişmelerin fotojurnalist çalışmalarda olay ya da olgulara dair gerçeklik temsillerine olan etkilerinin ortaya konulması amaçlanmaktadır. $\mathrm{Bu}$ amaç doğrultusunda öncelikle dagerotip ve ıslak kolodyum gibi ilk fotoğrafik tekniklerin kullanıldı̆̆ fotojurnalizmin başlangıç evresi araştırılmaktadır.

Fotojurnalizmin başlangıç evresinde kullanılan dagerotip ve ıslak kolodyum gibi ilk fotoğrafik tekniklerin yetersizlikleri, fotoğrafçıların konu ve detaylara uzak kalmasını sağlayarak gerçekliğin temsiline olan yaklaşımlarını sınırlandırmaktadır. Basın teknolojilerinin yetersizliğinden dolayı gazete ve dergilerde fotoğrafa yer verilemeyen bu dönemin teknik sınırlamaları, fotoğraftaki teknolojik değişimlerle orantılı şekilde aşılmaktadır. Özellikle elde taşınabilir, değiştirilebilir objektife sahip ve birden fazla fotoğraf çekme özelliğine sahip film kullanan $35 \mathrm{~mm}$ fotoğraf makinelerinin geliştirilmesiyle, teknik sınırlamalar ortadan kalkmakta ve farklı fotoğrafik üsluplarla gerçeklik aktarılmaktadır. Bu teknolojik gelişmelere ek olarak özellikle görsel ağırlıklı dergilerin yaygınlaşmasıyla fotojurnalizm, kurumsallaşarak modern çehreye kavuşmaktadır.

Televizyonun yayınlaştığı 1970'li yıllarda gerileme evresine giren fotojurnalizm, akademik çehrelerin ilgisini çeken, müze ve sanat galerilerinde sergilenen bir alan haline gelmektedir. Bununla birlikte aynı dönem içerisinde yeni fotojurnalizm anlayışı egemen olmaktadır. Yeni nesil fotoğrafçılar, renkli fotoğrafın fotojurnalizm içerisinde meşru bir araç olmasını sağlayarak, klasik fotojurnalizm anlayışını kökten değişime uğratmaktadırlar. Bu dönemde sembolik anlatımlardan ve çağdaş sanat unsurlarından faydalanılarak gerçeklik temsil edilmektedir. Diğer yandan dijital teknolojinin, fotoğrafı kökten dönüşüme uğratmasıyla fotojurnalizm çok daha farklı bir çehreye bürünmektedir. Dijitalleşen fotoğrafla, fotoğrafın nesnel gerçeklikle kurduğu bağ zayıflamaktadır. Böylelikle postfotoğraf olarak adlandırılan bu dönemde üretilen fotojurnalist çalışmalarda gerçeklik, dijital düzenlemelerin etkisinde ve kurgusal olarak aktarılmaktadır.

\section{Yöntem}

Araştırmada betimsel yöntem kullanılmaktadır. Literatür taraması yapılarak yazılı ve internet kaynaklarından faydalanılarak fotoğraf tekniğinde yaşanan teknik gelişim ve dönüşümlerin etkisindeki fotojurnalizm, başlangıç, modern ve post-fotoğraf dönemleri içerisinde ele alınmaktadır. Bu dönemler içerisinde fotojurnalist çalışmalarıyla fotoğraf tarihine mal olmuş fotoğrafçılar tarafından üretilen, amaca yönelik örneklem yoluyla belirlenmiş her bir döneme ait 3'er çalışma betimlenerek incelenmektedir.

\section{Fotojurnalizmin Tanım ve Kapsamı}

İcadıyla birlikte tüm toplumları derinden etkileyen fotoğraf, edindiği konuları nesnel şekilde yansıtma özelliğiyle diğer araçlardan ayrılmaktadır: "İlk defa olaraktır ki temel nesne ile bunun anlatımı arasına, bir başka nesnenin dışında herhangi bir şey girmemektedir. İlk defa olacaktır ki, dış dünyanın bir görüntüsü, insanın yaratıcılığı işe karışmaksızın, sıkı bir gerekirciliğe göre kendiliğinden meydana gelmektedir" (Bazin, 1966, s. 36). "Fotoğrafa konu alınan nesne ve fotoğraf arasındaki çok kuvvetli benzerlikler, onun diğer sanat ortamlarına oranla gerçeğe daha yakın bir yere sahip olmasına neden olmuştur" (Sağlamtimur, 2016, s. 650). Bu yönüyle fotoğraf, icat olduğu ilk zamanlardan itibaren kamuoyunu bilgilendirme amacıyla yazılı basında kullanılmaya başlanmıştır. Böylelikle fotoğraf içerisinde yeni bir alan ortaya çıkmıştır: Fotojurnalizm.

Yazılı basında önemli bir yere sahip olan fotojurnalizmin ana bağlamı; fotoğrafçının, kamuoyunu bilgilendirme amacıyla imaja yer verilen gazete, dergi ya da diğer kitle iletişim araçlarında yayınlamak üzere fotoğraf üretmesine dayanmaktadır (Walden, 2006, s. 454). Gazetecilikle yakından alakalı olan fotojurnalizm, haber anlatısının fotoğraflar ya da görseller üzerinden aktarılmasıdır. Haber niteliği taşıyan olayların görsel olarak haberleştirilmesi olarak fotojurnalizmin kökeni, fotoğrafların çekilmesi ve yayınlanmasına dayanır ve basın fotoğrafçılığı kavramının yerine geçmektedir (Caple, 2013, s. 3). Buna karşın fotojurnalizm, fotoğrafın sahip olduğu görsel ifadenin, haber anlatısıyla birleşmesinden meydana gelmektedir. Bu şekilde çekilen ve belli bir olayı haber amacıyla aktaran fotoğraf serilerini fotojurnalizm alanına dahil eden Hacking'e (2015) göre, fotoğrafların kendilerinin haber niteliği taşıması foto muhabirliği, basın fotoğrafçılığından ayırmaktadır (s. 555). Diğer yandan terim, uzun soluklu yapılan gazetecilik formuyla ilişkilidir ve genellikle kişisel bir bakış açısı barındıran metin ve fotoğrafların tek bir foto muhabir ya da ekip çalışması sonucu birleştirilmesi esasına dayanmaktadır (Harcup, 2014, 
s. 233). Bununla birlikte fotojurnalizm, nesnel gerçeklikle derin bağlar kuran fotoğrafın diğer yaklaşımlarıyla da yakın ilişki içerisindedir.

\subsection{Fotojurnalizmin Başlangıcı}

Fotojurnalizmin gelişmesinde fotoğraf ve bask1 teknolojilerindeki gelişmeler önemli rol oynamaktadır. Fotokimyasal tepkimelerle kalıcı bir görüntü yakalamanın ilk yolu olan dagerotip; ahşaptan yapılma büyük ve ağır fotoğraf makinesiyle ve yaklaşık 8 ile 20 dakikalarda gerçekleşen pozlama süreleriyle elde edilmektedir. Bu nedenle hareket içeren görüntülerin kaydedilmesi oldukça zordur. Diğer yandan 19. yüzyılın ortalarında basım teknolojileri fotoğrafın gazete ve dergi gibi yazılı basında kullanımına olanak vermemektedir. Buna karşın fotoğrafın her türlü gerçekliğe nesnel bir pencereden bakış açısı sağlayarak tanıklık etme özelliği, ilk fotoğrafçıların objektiflerini toplumsal olaylara yöneltmesini sağlamaktadır. Bu fotoğrafçılardan birisi de Alman portre fotoğrafçısı Hermann Biow’dur (1804-1850).

Biow, 1842 yılında Hamburg'da beş gün süren büyük yangını ve ardında bıraktığı enkazı farklı planlardan fotoğraflayarak kırktan fazla dagerotip üretmiştir. Biow’un dagerotipleri, kamuoyunun ilgisini çekebilecek toplumsal bir olayı ilk defa belgelenmesine örnektir ve o dönemin baskı teknolojilerindeki yetersizlikten dolayı gazete ve dergilerde yayınlanamamıştır. Buna karşın aynı yangına ait görsel, The Illustrated London News'ın sayfalarında farklı bir şekilde (Bkz. Görsel 1) yayınlanmaktadır: "Derginin illüstratörleri bu trajediyi göstermek için British Museum'a gidip eski bir Hamburg gravürünü kopyalar ve alevler ekleyerek durumu tasvir eden ama gerçek olmayan bir sahne yaratırlar" (Hacking, 2015, s. 50). Diğer bir deyişle Hamburg'un siluetini yansıtan gravürle, yangını nesnel şekilde gösteren Biow’un fotoğraflarıyla harmanlayan illüstratörler, bu toplumsal olayı öznel gerçeklik perspektifinde kamuoyuyla paylaşmışlardır. Bu olgunun temelinde basın teknolojisinin fotoğraf yayınlamaya elverişsiz oluşu yatmaktadır. Bununla birlikte kullanılan fotoğrafik yöntem, teknik anlamda sınırlayıcıdır; böylesine büyük çapta bir yangının yaydığı ışı, Biow’un ışığa daha az duyarlı ve uzun süre pozlama sürelerine sahip dagerotiple ürettiği fotoğrafların daha kolay çekilmesine olanak tanımaktadır.

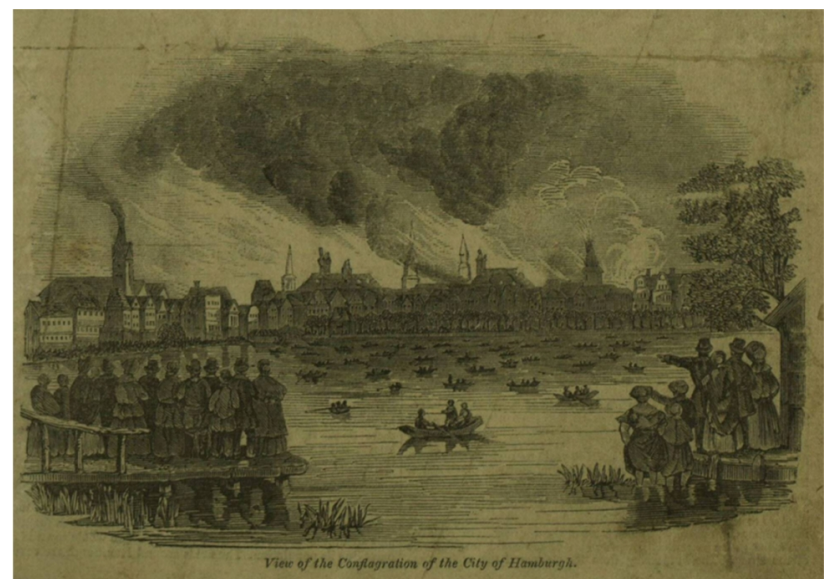

Görsel 1. The Illustrated London News, Hamburg Yangını, 1842

Objektifini toplumsal olaylara yönelten diğer bir fotoğrafçı da 1848 yılında siyasi çalkantılar sonucu Fransa'da çıkan işçi ayaklanmalarını belgeleyen Eugene Thibault'dır. Saint-Maur-Popincourt Sokağı'nda işçiler tarafından kurulan barikatların boş ve dolu hallerini dagerotip tekniğinden faydalanarak çeken Thibault'ın çalışmaları ahşap baskı tekniğiyle L'Illustration gazetesinde yayınlanmıştır. Diğer yandan işçi ayaklanmasının öncesine ve ayaklanma bastırıldıktan sonrasına (Bkz. Görsel 2) ait dagerotipler, sokağı olduğu gibi görecek şekilde tepe açıdan çekilmiştir. Bu açı, insan kalabalığına uzak bir konumdadır. Bunun temelinde, ağır ve hantal dagerotip makinesinin pratik şekilde taşımaya elverişsiz olmasının yattığı düşünülmektedir. Böylelikle Thibault, dolayısıyla da izleyici, konu ve detaylarına uzaktır. Diğer yandan sokakta bulunan insanlar, dagerotipin uzun süre pozlama dezavantajından dolayı net değildir. Diğer bir deyişle gerçekleri belgeleme konusundaki zorluklar, fotoğrafçıların konuya ve gerçekliğine olan yaklaşımlarını da etkilemektedir.

Gerçekleri belgeleme konusunda teknik zorluklarla karşı karşıya kalan ilk fotoğrafçılar, yangınların dışında dönemin önemli olayları arasında yer alan iç savaş, çatışma, ülkeler arası savaş, miting gibi toplumsal olayları da fotoğraflamaktadırlar (Sağlamtimur, 2011, s. 43). Fotoğraf tekniğindeki yetersizlikler, 1slak kolodyum tekniğinin geliştirilmesiyle bir nebze aşılmıştır. Pozlama sürelerinin dakikalardan, saniyelere indiği bu teknikten faydalanan Roger Fenton (1819-1869), 1855 yılında Kırım Savaşı'nı belgeleyerek ilk savaş fotoğraflarını çekmiştir. 


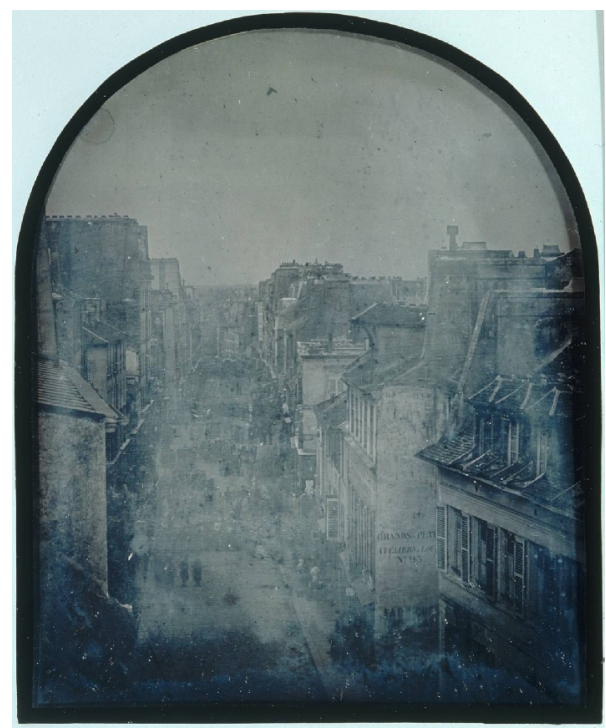

Görsel 2. Eugene Thibault, General Lamoricière'nin Birliklerinin Saldırlsindan Sonra Rue Saint-MaurPopincourt'daki Barikat, 1848

Fenton'un fotoğrafı (Bkz. Görsel 3) dönemin teknolojik yetersizliklerinden dolayı gravür yönteminden faydalanılarak The Illustrated London News'te (Bkz. Gravür 2) aslına sadık kalınarak yer almıştır. Fotoğrafçılığın kitle iletişim araçlarında oynadığı bu ilk önemli rolden sonraki on yılda, Amerikan İç Savaşı'nda, çatışmanın iki tarafının fotoğraflarının haberlerde yer alması fotoğrafçılığın gerçek potansiyelinin ortaya çıkmasına olanak tanımıştır (Smith, 2018, s. 27). Amerikan İç Savaşı'nı fotoğraflayan Matthew B. Brady (1822-1896), Timothy O'Sullivan (1840-1882) ve Alexander Gardner (1821-1882) gibi fotoğrafçıların çalışmaları, savaşın korkunç yüzünü kamuoyuna ilk defa somut bir şekilde göstermektedir.

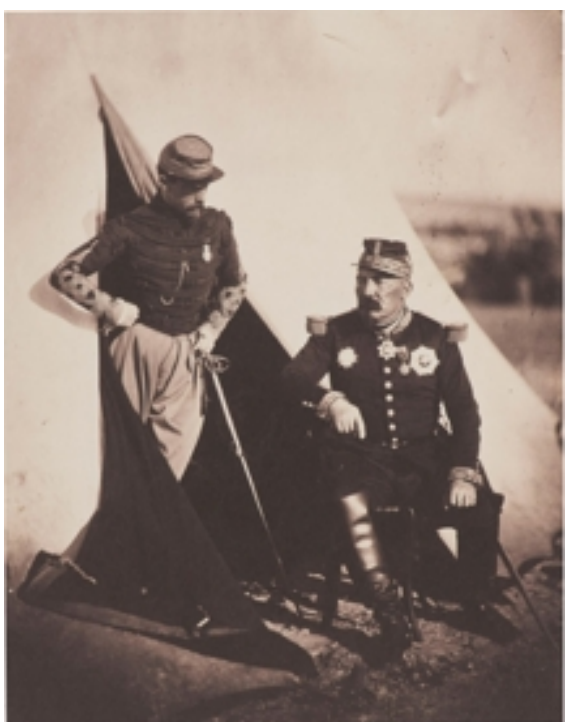

Görsel 3 Roger Fenton, General Bosquet ve Yüzbașı Dampierre, 1855

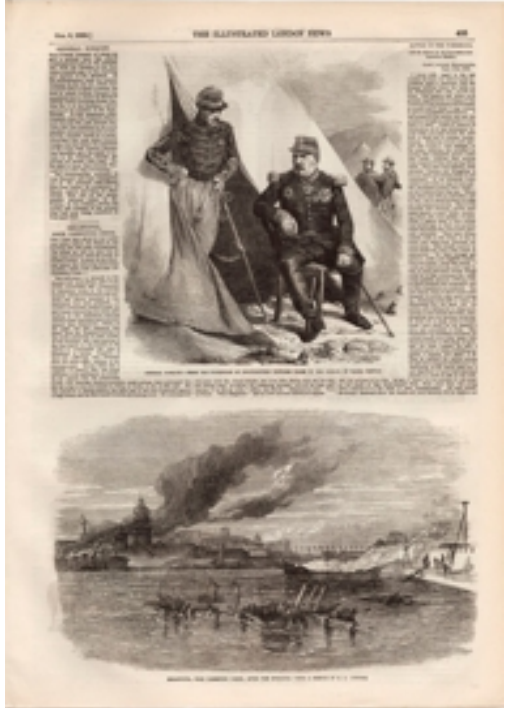

Görsel 4. The Illustrated London News, General Bosquet ve Yüzbașı Dampierre, 1855

Fotoğrafçıların sistematik olarak belgelediği ilk savaş olan Amerika İç Savaşı'nda çekilen fotoğraflardan birisi de Ölümün Hasatt'dır (Bkz. Görsel 5). O'Sullivan'ın, Garder için çalıştı̆ı dönemde, Gettsburg Savaşı'na ait bu çalışma 1slak kolodyum tekniğinden faydalanılarak üretilmiştir. Kameraya yerleştirilerek pozlamaya maruz kalmadan hemen önce negatif olarak kullanılan camın kolodyum ile kaplanması işlemi nedeniyle 1slak levha olarak da bilinen bu teknik, özellikle sahada kullanılması zor bir yöntemdir (Senf, 2008, s. 1017). Bununla birlikte çatışmanın ardından Birlik askerlerine ait cesetlerin arazi üzerinde yatmakta olduğu bu çalışma incelendiğinde standart bir göz seviyesinden bakış açısı kullanmak yerine fotoğraf makinesini zemine yakın bir yere yerleştirilerek konuya odaklanıldığı gözlemlenmektedir. Böylelikle O'Sullivan, savaşın kazanan tarafını güçlendirmekten ziyade, izleyiciyi savaşın gerçekliğiyle yüzleşmesine zorlamaktadır. Diğer yandan O'Sullivan'nın bu çalışması, tıpkı diğer Amerika İç Savaşını takip eden fotoğrafçıların çalışmalarında da olduğu gibi çatışma anına dair 
olmaktan ziyade, çatışmalar sona erdikten sonra fotoğraflanmıştır. Bu olgunun temelinde islak kolodyumun getirdiği teknik zorluklar bulunmaktadır: Işığa duyarlı cam levha hazırlandıktan hemen sonra, 1slak kolodyum tam olarak kurumadan, makineye yerleştirilerek pozlanmakta ve bu aşamadan kısa bir süre sonra banyo işleminin gerçekleştirilmesi gerekmektedir. Diğer yandan bu teknikte pozlama süresi, 1şı̆̆ın yoğunluğu, kullanılan kolodyumun yaşı ve kalitesine göre bir saniyeden birkaç dakikaya kadar değişiklik göstermektedir. Ayrıca fotoğraf makinelerinin büyüklüğü göz önünde bulundurulduğunda savaş esnasında çatışma anına dair görüntülerin çekilebilmesi teknik anlamda zordur. Dolayısıyla da tıpkı O'Sullivan'ın çalışmasında olduğu gibi bu savaşa tanıklık eden fotoğrafçılar savaş sonrası görüntülere odaklanmaktadırlar. Buna karşın yakılıp yıkılan arazilerin, yangınla kül olmuş evlerin, felakete uğramış ailelerin ve sayısız ölünün görüldüğü fotoğraflardaki nesnellik, bu belgelere farklı bir değer katmaktadır (Freund, 2006, s. 98). O’Sullivan ve diğer Amerika İç Savaşını belgeleyen fotoğrafçılar, teknik zorluklara karşın ürettikleri çalışmalarında savaşın çirkin yüzünü somut şekilde yansıtmaktadırlar. Amerika İç Savaşı'na dair bu değerli çalışmaların gravür yöntemiyle yazılı basında yer almasıyla halkın savaş sahnelerine olan arzusunun farkına varan yayıncılar, savaşın çirkin yüzünü somut şekilde yansıtan fotoğrafların çekilmesini ve yayınlanmasını desteklemeye başlarlar.

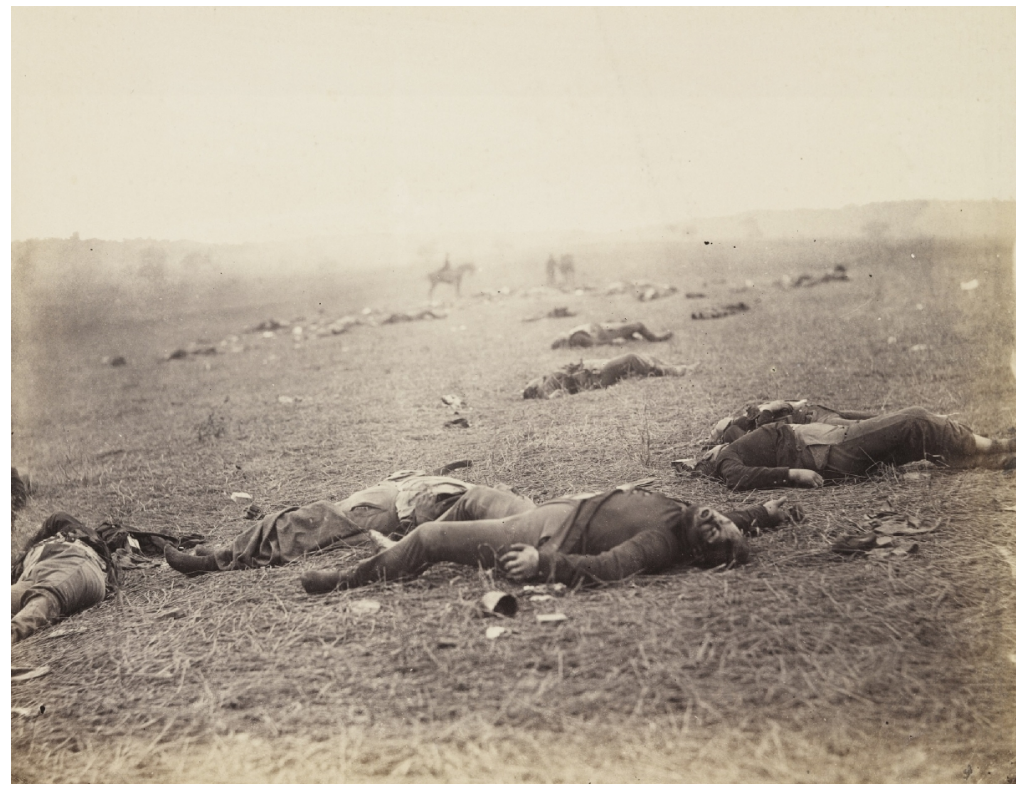

Görsel 5. Alexander Gardner ve Timothy O’Sullivan, Ölümün Hasatı, 1863

İcat olduğu ilk zamanlardan itibaren basınla yakın ilişki kurmasına rağmen basın teknolojilerindeki yetersizlikten dolayı gazete ve dergilerde birebir yer alamayan fotoğraf; 1880 yılında yarım ton baskl yönteminin geliştirilmesiyle haber muhabirliğinin vazgeçilmez bir parçası haline gelmiştir. "4 Mart 1880'de ilk basılı fotoğraf, New York Daily Graphic'de Stephen Henry Horgan'ın Shantytown (Gecekondu Mahallesi) ismiyle çıkar" (Amar, 2009, s.36). Bununla birlikte fotoğrafın yazılı basın içerisinde yer almasını sağlayan tek gelişme basın teknolojileriyle sınırlı değildir; 19. yüzyılın sonlarında fotoğrafta yaşanan teknik ilerlemeler de fotoğraf ve basın arasındaki ilişkiyi sağlamlaştırmaktadır. Freund'a (2006) göre, fotoğraf çoğaltmanın mekanikleşmesi, hazırlanmasının ardından üzerinden belirli bir süre geçtikten sonra bile kullanılabilen kuru jelatin plakaların icat edilmesi (1871), 1şık geçirgenliği yüksek anastigmat objektiflerin geliştirilmesi (1884), rulo film (1884), görüntünün telgraf yöntemiyle aktarılması konusundaki ilerlemeler (1872) ve daha sonraları telefon hattı üzerinden uzak mesafelere fotoğraf aktarımını sağlayan belinografın geliştirilmesi (1907), basın fotoğrafçılığına giden yolu açmıştır (s. 95-96). Bununla birlikte 1907 yılında Berlin ve Paris arasında ilk foto-telgraf hattının kurulmasından sonra çok sayıda fotoğraf, dünyayla eş zamanlı olarak kullanıma sokulmaya başlanmıştır (Yaykın, 2010, s. 19). Bu teknik gelişmeler perspektifinde fotoğraf; sadece portre, ticari ya da sanatsal alanlar dıșında toplumu derinden etkileyen olaylara, sosyolojik olgulara, diğer bir deyişle toplumu yakından ilgilendiren gerçekliklere odaklamaya başlamıştır. Fotojurnalizm bu gerçekliklerin tamamını, kamuoyunu bilgilendirecek şekilde bünyesine katan bir alan haline gelmiştir. Fotoğrafta bu alanın gelişmesinde önemli rol oynayan fotoğrafçılardan birisi de Tribune'da gazeteci olarak çalışan Jacob A. Riis'dir.

Danimarkalı fotoğrafçı bir ilke imza atar ve New York’un aşağı mahallelerinde sefil hayatlar süren göçmenlerin yaşam koşullarını anlattığı yazılarını, görüntülerle güçlendirmek için fotoğraftan faydalanır ve böylece fotoğraf, ilk defa toplumsal eleştiri malzemesi haline gelmiştir (Freund, 2006, s. 99). Riis'in çalışmalarından oluşan Öteki Yarı Nasıl İşler adlı kitabı 1890 yılında yayınlandıktan sonra kamuoyunu derinden etkilemiştir. Böylelikle gerçekliği tüm nesnelliğiyle yansıtan fotoğrafın, toplumsal yaşantının tüm katmanlarına sirayet eden bu özelliğiyle basılı yayının ilgisini çekmeye başlamıştır. Amerikalı sosyolog Lewis W. Hine'da fotoğrafın bu özelliğinin 
farkındadır. Ulusal Çocuk İşçiler Komitesi tarafından temsilci olarak görevlendirilen Hine, 1908 ile 1917 yılları arasında Amerika'daki çocuk iş̧̧ilerin kötü koşullar altındaki yaşamlarına odaklanmaya başlamıştır. "Hine, bu süre zarfında on binlerce kilometre yol kat ederek genellikle güney, güneydoğu ve doğu eyaletlerinde haftada altı gün, günde 10 ile 14 saat boyunca madenler, değirmenler gibi her tür çeşitten fabrikada kabul edilemez koşullarda insafsızca ucuza çalıştırılan çocukları fotoğrafladı" (Gordon, 2006, s. 698). Hine'ın bu fotoğrafları kamuoyunda ses getirerek, çocuk işçilerin çalışma koşullarının iyileştirilmesi adına yasal düzenlemelerin yapılmasına olanak tanımıştır. Böylelikle fotoğraf, toplumdaki yoksul kesimlerin yaşam koşullarını iyileștirmek adına kullanılabilecek bir silaha dönüşmüştür (Freund, 2006, s. 99). Fotoğrafin günlük yayınlanan gazetelerde yaygın kullanımı da bu dönemlere tekabül etmektedir. Amar'a (2009) göre, Pierre Laffitte, 1910 yılında fotoğraflı ilk günlük gazete L'Excelsior'u yayınlamıştır. Ancak bu fotoğrafların basılması için en iyi ihtimalle iki gün gerekmektedir ve çok fazla masraflıdır. Diğer yandan 1919 yılından itibaren New York'ta yayınlanan L'Illustradet Daily News, gerçek anlamda düzenli olarak fotoğrafı kullanmaya başlamıştır (s. 37). Fotoğrafin 20. yüzyılın baş̧ında dergi ve günlük yayınlanan gazetelerde düzenli kullanılmaya başlanması, kitlelerin dünya görüşünü derinden etkileyecek bir olgudur. Freund (2006) bu olguyu şu şekilde açıklamaktadır:

O güne kadar sokaktaki insan, ancak yakınında yani kendi sokağında, mahallesinde gerçekleşen olayları gözünde canlandırabiliyordu. Fotoğrafla birlikte dünyayı görmeye başladı. Kamuoyuna mal olmuş kişilerin yüzleri, ülkenin farklı bölgelerinde hatta sınır dışında gerçekleşen olaylar, herkesin yakınına taşındı. Bakışın genişlemesiyle birlikte dünya küçüldü. Yazılı sözcükler soyuttur, ama fotoğraf, herkesin içinde yaşadığı dünyanın somut yansımasıdır (s. 96-97).

Fotoğrafin kamuoyu üzerindeki bu gücü, 1924 yılında çok az ışı̆̆ın bulunduğu ortamlarda rahatlıkla fotoğraf çekme olanağı tanıyan bir objektife sahip Ermanox'un geliştirilmesiyle farklı bir noktaya taşınmıştır. Bununla birlikte en önemli bulus, 1925 'te Leitz firması tarafindan $35 \mathrm{~mm}$ rulo film kullanan Leica fotoğraf makinesinin piyasaya sürülmesidir. “... Oscar Barnack tarafından 1913'de sinema filmlerinin çekiminde kullanılan 24 x 36'llk ebattaki bu makine, özellikle de değiştirilebilir objektiflerle donatıldıkları andan itibaren pek çok basın fotoğrafçısının makinesi haline gelecektir" (Amar, 2009, s. 53). Diğer bir deyişle 20. yüzyılın ilk çeyreğinde yaşanan teknik gelişmeler ışığında, geniş diyafram açıklığı ve değiştirilebilir lenslere sahip rulo film kullanılan, daha kompakt yapıya sahip fotoğraf makineleri piyasaya sunularak, fotoğraf çekmek daha pratik hale gelmiştir. "Bu yeni kameralar fotoğrafçıları oldukça hareketli hale getirdi ve dikkat çekmeden harekete geçmelerini sağladı" (Pohlad, 2006, s. 717). Bu değişimden fotojurnalizm de etkilenerek fotoğrafın kamuoyu üzerindeki ses getiren gücünü daha kuvvetli hale getirmiştir.

Fotoğrafın bu gücünü fark eden Roy Stryker, 1920'li yılların sonunda Amerika Birleşik Devleri'nde (ABD) yaşanan Büyük Buhran'ın toplumsal etkilerini belgelemek için Çiftlik Güvenlik Kurumu (FSA) desteğiyle fotoğraf ekibi oluşturmuş̧ur. "Yoksul çiftçilerin durumunu belgelemek için pek çok fotoğrafçı ve yazar FSA Bilgi Bölümü’nde işe alındı. Bu fotoğrafçı ve yazarlar, basına bilgi vermek konusunda ülkenin en sorumlu kişileri sayıldılar" (Ok, 2016, s. 165) Böylelikle Walker Evans (1903-1975), Dorothea Lange (1895-1965) ve Gordon Parks (1912-2006) gibi fotoğrafçılardan oluşan ekip, ekonomik krizden en çok etkilenen kırsal bölgelerde çektikleri fotoğraflarla Büyük Buhran'ı belgeleyerek fotojurnalizmin gelişmesinde önemli rol oynadılar. "Lewis Hine gibi fotoğrafçılar daha önce, giderek mekanikleșen bir toplumu vurgulamış, Çiftçi Güvenliği İdaresi'nin fotoğrafçılarıysa pastoral bir belgesel biçimine doğru ilerlemiş̧ir" (Smith, 2018, s. 80). Bununla birlikte Büyük Buhran Dönemi ile ilişkili en bilinir fotoğraf, 1935 yllında FSA fotoğrafçılarından birisi olan Dorothea Lange'a aittir.

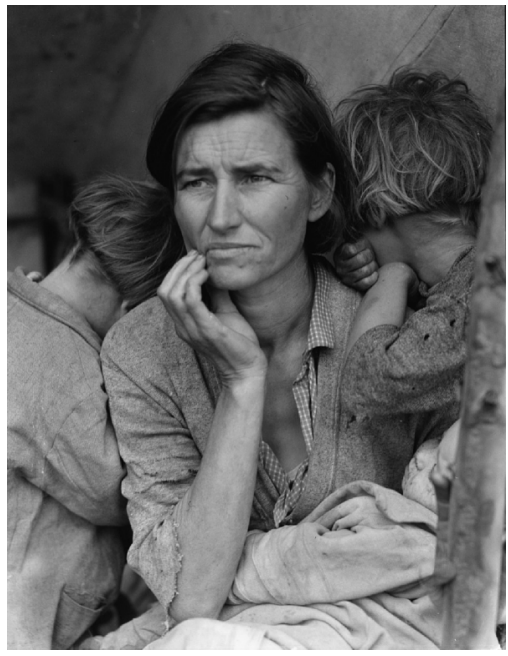

Görsel 6. Dorothea Lange, Göçmen Anne, Nipomo, Kaliforniya, 1936 
Lange’nin sadece Büyük Buhran'da yaşanan sıkıntılarla özdeşleşmekle kalmayıp FSA projesi içerisinde üretilen belki de en tanınmış fotoğrafı, Göçmen Anne, Nipomo, Kaliforniya'dır (Bkz. Görsel 6). Bu çalışma, yaşanan ekonomik krizin toplum üzerindeki etkisini belgelemek için Lange'in kırsal bölgelere çıktığı gezide karşılaştığı 7 çocuklu Florence Owens Thompson'a ait portredir. Lange, Nipomo Ovası'nda bezelye toplayan işçilerin bulunduğu kampta, binlerce göçmenin arasından tesadüfen tanıştığ 1 Thompson'1 10 dakika içerisinde sadece birkaç kare (Bkz. Görsel 7) çektikten sonra bu fotoğrafı elde etmiştir. Bu fotoğraflar incelendiğinde Lange'in, Thompson ve çocuklarını göz hizasından ve farklı açı ya da uzaklık-yakınlıklardan çektiği gözlemlenmektedir. Diğer yandan fotoğraflara konu edinilen özneler her bir karede farklı duruş ve eylem içeresindedir. Bununla birlikte Göçmen Anne, Nipomo, Kaliforniya'yı diğer karelerden daha güçlü ve etkili kılan ise bu fotoğrafın, yoksulluk içerişindeki çaresiz çocukların yüzlerini mahcupluk içerisinde saklayarak annelerine sığınma hallerini göstermesidir. "Bakımsı, masum çocukların yüzlerini fotoğraf makinesinden saklamaları, dikkatimizin merkezdeki Meryem Ana benzeri figürde toplanmasına neden olur" (Smith, 2018, s. 80). Diğer yandan bu ekonomik krizin getirdiği umutsuzluk, Thompson'ın elini çenesiyle buluşturup gözlerini uzaklara diktiği çaresiz haliyle bütünleşmektedir. Ayrıca ailenin yoksulluğu Thompson ve çocuklarının kıyafetlerinden rahatlıkla anlaşılabildiği gibi fotoğrafın arka planında gözüken ve ailenin yaşam alanını oluşturan çadırdan da anlaşılmaktadır.
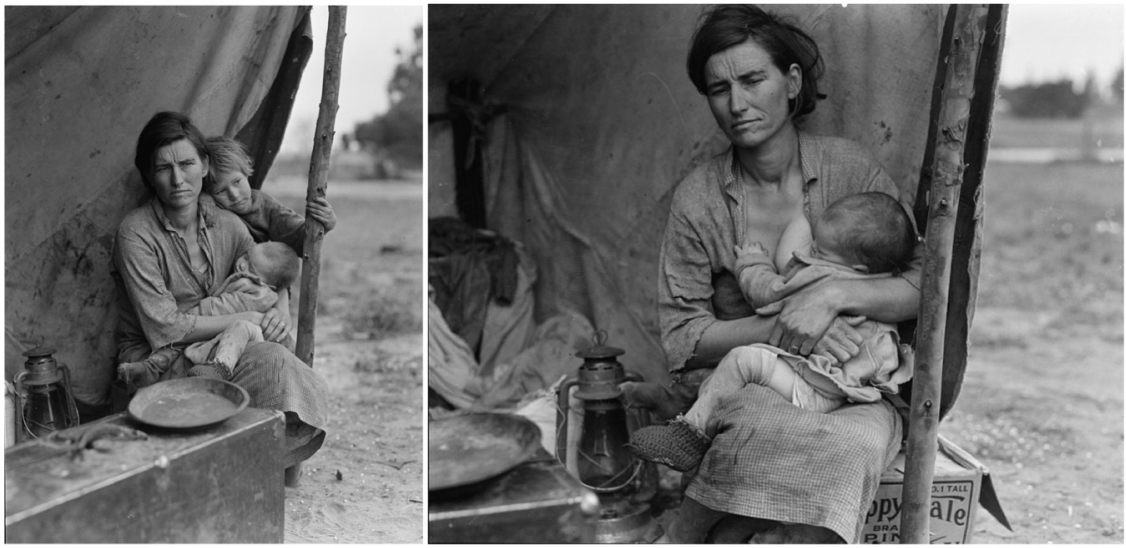

Görsel 7. Dorothea Lange, Kaliforniya'da Yoksul Bezelye Toplayıcı 1 ve 2, 1936

Göçmen Anne, Nipomo, Kaliforniya adlı fotoğraf, küçük ebatlarda hafif bir fotoğraf makinesinin verdiği hareket kabiliyeti ve $35 \mathrm{~mm}$ rulo film kullanmanın yaklaşık 36 poz çekebilmenin sağladığı pratiklikle Lange'in, aynı konu dahilinde birden fazla fotoğraf çekmesinin sonucu ortaya çıkmıştır. Bu pratiklik, fotoğrafçıların objektiflerini yönelttikleri konunun gerçekliğini en kuvvetli şekilde anlatacak kadrajı yakalamalarına olanak sağlayarak, temalar üzerinden olayları betimleme eğilimini kolaylaştırmaktadır: "Lange burada tek bir kişiye odaklanır ve onu bir birey olarak değil, bir arketip olarak portreler. FSA'nın Büyük Buhran Dönemi'nin kurbanlarını annelik ve aile gibi geleneksel temalar üzerinden betimleme eğilimi de burada görülür” (Stetler, 2015, s. 311). Başta Lange'in çalışmaları olmak üzere diğer FSA fotoğrafçılarının Büyük Buhran Dönemi'nde ürettiği fotoğraflar, fotojurnalizmin gelişmesinde önemli bir rol oynamıştır. Diğer yandan fotojurnalizmin gelişmesindeki diğer bir etken de aynı dönemlerde Alman basınında görsel ağırlıklı dergilerin yayınlanmaya başlamasıdır.

1. Dünya Savaşı'nın sona erdiği yıllardan başlayarak, 1930'lu yıllara kadar Almanya'da Münchner Illustrierte Presse ve Berline Illustrierte gibi onlarca haftalık dergi yayınlanmaya başlamıştır. "Bu dergiler çoğunlukla meraklı ve kültürlü okuyucuların talebine cevap vermek için her türlü konuyu ele alır. Röportajlar, spor, sinema ya da etnografi kadar sosyal hareketlerden de bahsetmektedir" (Amar, 2009, s. 54). Bu dergilerde işlenen konular izleyiciye daha çekici kılınmak adına mizanpaj için önemli çabalar harcanmıştır: Fotoğraflar yeniden kadrajlanmakta ve görüntü ağırlıklı anlatılara ağırlık verilmektedir. Bununla birlikte dergilerde mizanpaj yapan sanat yönetmenleri sayfa düzeni yaparken kullandıkları fotoğrafların konumunu, büyüklük ya da küçüklüklerini ayrıca devamlılıklarını sağlayarak onlara anlam katmaktadırlar. Mizanpaj alanındaki bu yeniliklerin öncüsü eski bir kameraman ve kurgucu Stefan Lorant'tır (1901-1997). Lorant, görsel kullanımıyla öncü niteliğindeki Münchner Illustrierte Presse'nin baş editörü olmasıyla, sinematografi alanındaki deneyimlerini, dergi yayıncılığında fotoğraf kullanımına büyük bir etki sağlayacak şekilde aktarmıştır. "Ermanox ve Leica gibi modern küçük formatlı kameralardan kaynaklanan samimi fotoğrafçılık tarzını, baskı süreçlerindeki gelişmelerden de yararlanarak, yeni bir okur-yazar kitlesine tanıttı. Lorant, sinema hissini düşündüren görüntülerin dergide bir görsel anlatım biçimi oluşturacak şekilde mizanpajının yapılması konusunda bir ustaydı" (McDonald, 2006, s. 1266). Diğer bir deyişle Lorant, dergi içeriğini oluşturan konuları birden fazla fotoğraftan oluşan görsel hikâyelerle desteklemektedir. Böylelikle Münchner Illustrierte Presse görsel ağırlıklı öncü dergi haline gelerek okuyucu alışkanlığını kökten değiştirmiştir ve yazılı basında fotoğrafla hikâye anlatımı ön plana çıkartarak fotojurnalizmin 
gelişmesine katkı sağlamıştır. Diğer yandan Lorant, "Felix Man, Alfred Eisenstaedt ve Robert Capa gibi etkili fotoğrafçıların kariyerlerini desteklemesinin yanı sıra, o zamanlar ortaya çıkmakta olan foto muhabirliği mesleğinin en temel ilkelerinin çoğunu formüle etti” (Stefan Lorant, parag. 2). Lorant, fotojurnalizme olan katkılarını, Nazi İktidarının başa geçmesiyle göç etmek zorunda kaldığı İngiltere'de devam ettirerek Weekly Illustrated, Lilliput ve Picture Post gibi ülkenin en popüler görsel ağırlıklı dergilerin fikir ve kuruluş aşamasında bulunmuştur.

Özellikle 20. yüzyılın başlarında 35mm fotoğraf makinelerinin geliştirilerek yaygınlaşmasıyla toplumsal olayların daha rahat fotoğraflanarak geniş kitlelerle paylaşılmaya başlanmaktadır. Diğer yandan basın teknolojilerinde yaşanan gelişmeler ışığında fotoğrafın yazılı basında yaygın ve düzenli kullanıma başlanmasıyla fotojurnalizm; kurumsal boyut kazanarak modern bir çehreye kavuşmaktadır. Fotojurnalizmin kurumsallaşmasında, bünyesinden birden fazla foto muhabir barındıran $V u$ Dergisi'nin yayınlanması önemli bir rol oynamaktadır.

\subsection{Modern Fotojurnalizm}

Alman basınındaki gelişmelerden etkilenen Lucien Vogel (1886-1954), Fransa'da politik bir perspektife sahip ve haftalık çıkan $V u$ Dergisini 1928 yılında yayınlamaya başlamıştır. Yayın hayatını 12 yıl sürdüren $V u$, "Vogel'e göre 'bir eylem aracı, bir ifade biçimi' olmalıdır" (Amar, 2009, s. 57). Diğer yandan dergide görsel kullanımı ön planda tutulmuştur. Bu bağlamda Andre Kertesz (1894-1985), Germaine Krull (1897-1985), Henri CartierBresson (1908-2004), Eli Lotar (1905-1969), Brassai (1889-1984) ve Robert Capa (1913-1954) gibi farklı üslup ve tekniklerden faydalanarak çalışmalar üreten fotoğrafçılar, Vu'nun görsel anlamda bir eylem aracı, bir ifade biçimi haline gelmesinde önemli rol oynamışlardır. Kempf'e (2006) göre, dergide yayınlanan başta Paris ve ülkenin gündelik yaşamını araştırdığı çalışmalarında Kertesz; eleştirel bir yaklaşımla, modern yaşamın insanlıktan çıkma eğilimini, ironik paradoksları ve garip karşılaşmaları çoğunlukla gerçeküstücülüğe yakın bir noktada vurgulamaktadır (s. 736). Diğer yandan Robert Capa'nın İspanya İç Savaşı'nda çekmiş olduğu fotoğraflar da aynı dergide yayınlanmıştır. Bununla birlikte derginin içeriğini oluşturan haber ya da konulara dair metinler, bir dizi fotoğraf serisiyle yayınlanmaktadır. Böylelikle $V u$, fotojurnalistik çalışmaları dergi formatında sunan öncü bir yayın olarak Life ve Picture Post gibi dergilerin ilham kaynağı haline gelmiştir.

Vu Dergisini model alan Henry Luce (1898-1967), 1936'da Life'1 yaratarak, ABD'de yayınlamaya başlamıștır. "Luce, fotoğrafların; haberleri iletebileceği, hikâyeler söyleyebileceği ve editoryal bakış açısına odaklanabileceği öngörüsüyle görsel ağırlıklı bir dergi yayınlamaya karar verdi” (Weintraub, 2006, s. 236). Böylelikle başlarda haftalık yayınlanan dergi, içeriğinde bulunan fotoğraf ve görsellerin gücünü arttırmak için kușe kâğı̆t üzerine basılmıştır. Diğer yandan "Luce, ajanslardan gelen aktüalite klişelerini, fotoğrafin büyük isimleri tarafindan gerçekleştirilen fotoğraflı yazılarla birleştirecektir. Metinler daha çok haberi tamamlayıcıdır, zira üstünlük görüntüdedir” (Amar, 2009, s. 60). Dolayısıyla Life, güçlü bir fotoğraf kadrosunu bünyesinde barındırmaktadır.

Life'ın fotoğraf kadrosunu; fotojurnalizmin babası olarak adlandırılan ve zamanın önde gelen foto muhabiri Alfred Eisenstaedt (1898-1995), modern Amerika'nın en ikonik görüntülerinden bazılarını yaratan Andreas Feininger (1906-1999), 18 yılda 5 savaş fotoğraflayan "belki de şimdiye kadarki en büyük savaş fotoğrafçısı..." (Weintraub, 2006, s. 236) Robert Capa, medeni haklar, yoksulluk ve özellikle Afro-Amerikalılar konularında çalışmalar üreten Gordon Parks (1912-2006), çektiği portre fotoğrafları Life'ın onlarca kapak sayfasına taşınan Philip Halsman (1906-1979) ve 1946'dan 1952'ye kadar 50'den fazla foto-röportaja imza atan W. Eugene Smith (1918-1978) gibi fotoğrafçıları oluşturmaktadır.

Bünyesinde barındırdığı zamanın önde gelen fotoğrafçılarıyla Life, ABD kültüründe fotoğrafçılığın rolünün gelişmesinde önemli bir rol oynamıştır. "Fotoğrafç̧1ık, ABD görsel kültürünü 20. yüzyılda derin bir biçimde değiştirdi ve Life'ın foto-röportajları incelikli ve tutarlı kullanımı, bu değiş̧ime katkıda bulundu" (Stomberg, 2006, s. 953). Sadece ABD ile sınırlı kalmayıp tüm dünyanın görsel kültürünü derinden etkileyen Life bünyesinde yer alan diğer bir fotoğrafçı da Henri Cartier-Bresson'dur (1908-2004).

Cartier-Bresson, yaşadığı yüzyılda çalışmalar üreten meslektaşlarını derinden etkileyecek karar anı kavramını belirleyen vizyoner bir fotoğrafçıdır. Ressamlık kökeninden gelen sanatçı, başlangıçta Sürrealistlerin amaçsız keşif yürüyüşleri'nden etkilenerek 1930'lu yılların başında Avrupa'yı Leica fotoğraf makinesiyle gezmeye başlamış̧ır. "Bresson yabancı topraklarda dolaşırken asgari düzeyde dikkat uyandırdığı kadar hareket kolaylığı da sağlayan elde tutulan Leica ile bohem spontanlığını, ressamlığın getirdiği kompozisyon hissiyle eşleştiren imgeleri çekti” (Henri Cartier-Bresson, parag. 1). Günlük hayatın sıradan dramlarını belgeleyen Bresson, Life için 1937 yılında Kral VI. George'un taç giyme törenini fotoğraflamıştır. Bu seri içerisinde yer alan Trafalgar Meydanı adlı çalışmada (Bkz. Görsel 8) Cartier-Bresson, objektifini taç giyme törenin kendisinden ziyade töreni izleyen daha az imtiyazlı seyircilere çevirmiş̧tir. Daha sonrasında bu tutum, en az 1970'li yıllara kadar devam eden gerçek bir fotojurnalizm ekolü yaratmaktadır: Analiz, olgulardan üstündür. (Amar, 2009, s. 62). Diğer bir deyişle CartierBresson'un olgundan ziyade analizle odaklanarak konun gerçekliğini farklı bir anlatım yöntemiyle aktarmasını sağlayan bu üslubun ortaya çıkmasında, $35 \mathrm{~mm}$ fotoğraf makinesi ile teknik zorluk ve sınırlamaların aşılması yatmaktadır. Cartier-Bresson'un bu ufuk açan vizyonu, Life ve dergi ekibini oluşturan diğer fotoğrafçılar, modern 
fotojurnalizm için önemli yere sahiptirler. Diğer yandan modern fotojurnalizm için önem arz eden diğer bir dergi de $V u$ 'dan esinlenerek yayın hayatına başlayan Picture Post'tur.

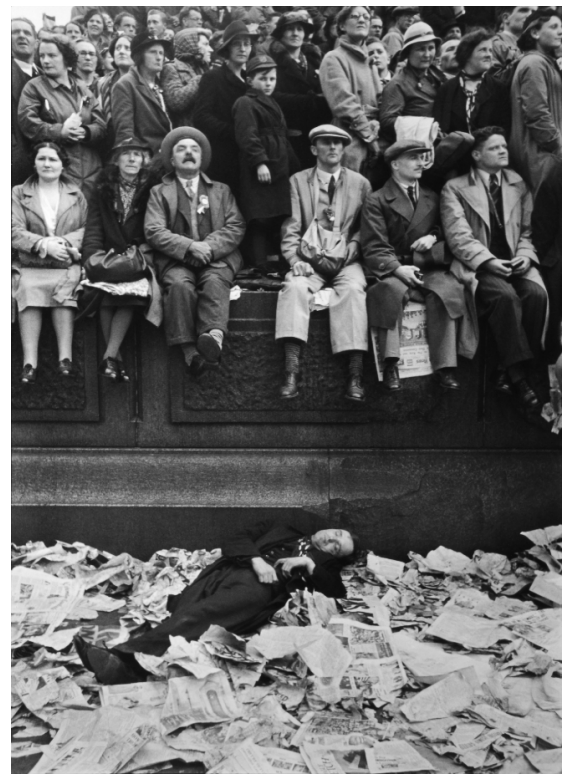

Görsel 8. Henri Cartier-Bresson, Trafalgar Meydanı, Londra, 1937

Macar asıllı Stefan Lorant'tın İngiltere'de 1938 yılında piyasaya sürdüğü ve sosyal- politik hayatın nabzını tutan Picture Post, 20 yıllık yayın hayatında fotojurnalizm için öncü bir yayın olmuştur. Lorant, bu dergiyle; diplomatik ve yüksek mevkidekileri fotoğraflayan Erich Salomon (1886-1944), Bauhaus Ekolünün önde gelen fotoğrafçılarından Umbo (1902-1980), spordan modaya farklı alanlarda dinamik çalışmalarıyla ünlenen Martin Munkacsi (1896-1963) gibi fotoğrafçıların çalışmalarını tanıtmıştır. Lorant gibi Nazi Almanya'sından kaçmak zorunda kalan bu fotoğrafçıların çalışmaları, Haywood Magee, Leonard McCombe ve adı Picture Post ile eşanlamlı olan Bert Hardy de dahil olmak üzere yeni nesil İngiliz fotoğrafçılarını etkilemiştir (McDonald, 2006, s. 1267). Bununla birlikte Picture Post ve Life gibi görsel ağırlıklı haber dergilerinin yükselişiyle fotojurnalizm, 1920'lerin ortalarından 1960'lara kadar en başarılı dönemini yaşamıştır. "Bu dönem; spor, toplum ve suç fotoğrafçılığında olağanüstü ilerlemelere sahne oldu, çağın en önemli çatışmalarının fotoğrafını çeken foto muhabirleriyse aksiyonla hiç olmadığı kadar yakınlaştılar” (Smith, 2018, s. 27). Böylelikle foto muhabirlik; savaş, siyaset, spor, kültür ve toplumsal-sosyal sorunlar gibi çeşitli alanlarda önemli bir rol oynamaya başlamıştır. Diğer yandan görsel ağırlıklı dergilerin yaygınlaşmasının sonucu ortaya çıkan modern fotojurnalizmin, fotoğraf ajanslarının kurulmasıyla gelişmeye devam etmektedir. Bu ajanslardan en önemlisi Magnum Fotoğraf Ajansıdır.

Magnum, İkinci Dünya Savaşı'nın ardından, 1947 yılında, dört öncü fotoğrafçı tarafindan kurulmuştur. Henri Cartier-Bresson, Robert Capa, George Rodger (1908-1995) ve David Seymour'un (1911-1956) girişimiyle kurulan Magnum, farklı kişisel fotoğrafik üsluplara sahip önemli fotoğrafçıların bir araya geleceği kooperatif mantığıyla sürdürülen fotoğraf ajansıdır. Kooperatif modeliyle kurulan ajans, üyesi olan fotoğrafçıların, görev sırasında çekilen tüm fotoğraflarının haklarını elinde bulunduran dergilerden kurtarma hedefini taşımaktadır (Hacking, 2015, s. 326). Böylelikle Magnum fotoğrafçıları, çektikleri fotoğrafları ajansın arşivinde tutmakta ve çalışmalar, telif karşılığında basın kuruluşları tarafından kullanılmaktadır. Bunun sonucu olarak Magnum fotoğrafçıları, bu telif haklarından edindikleri finansman desteğiyle uzun soluklu projelerine daha fazla zaman ayırabilmektedirler. Diğer yandan "Magnum, kuruluş ideallerini sürdüren kendine özgü gazeteci, sanatçı, hikâye anlatıcılarını ve dünyanın bazı en ünlü fotoğrafçılarından oluşan bir birlikteliği temsil eder" (About Magnum, parag. 2). Bununla birlikte Magnum fotoğrafçıları; dünyanın kronik sorunları ve insan, kültür ayrıca coğrafyaları konu edindikleri güçlü hikâyeleriyle, statükoları tanımadan, tarihi ve yaşamları değiştiren bir vizyon paylaşmaktadır. Bu vizyona sahip farklı üsluplarla çalışan fotoğrafçıların Magnum için ürettikleri çalışmalarda, foto muhabirlik ve sanat arasında gidip gelen ilişkinin yansımalarını görmek mümkündür. Hacking'e (2015) göre,

Yelpazenin bir ucunda Capa'nın kusursuz olmaktan uzak, 'o an' orada olmaya dayalı üslubu, tam karşı uçta ise Cartier-Bresson'un üzerine düşünülmüş, kontrollü fotoğrafçılık tarzı yer alıyordu. Tüm Magnum fotoğrafçılarında ortak olan nokta ise her birinin çektikleri fotoğrafları, foto muhabirlik geleneğindeki anlatı unsurlarına sadık kalarak yani bir öyküyü meydana getirecek şekilde bir araya getirmesidir (s. 327).

Magnum'un farklı üsluba sahip fotoğrafçıları bünyesinde barındırma politikası, 1970'lerde de devam ederek fotojurnalizmin gelişmesinde önemli rol oynamaktadır. Bu yıllarda Magnum bünyesinde uzun soluklu fotoröportajlara imza atan bir fotoğrafçı da W. Eugene Smith’tir (1918-1978). Amerikalı foto muhabir Smith, 1957 
yılında Magnum'a tam üye olarak kabul edilmeden önce Life gibi önemli dergiler için foto-röportajlar hazırlamıştır. Bu dönemde Pasifik Savaşı'nda (1942-1945) 32 operasyona katılarak bunları belgelemiştir. İkinci Dünya Savaşı'ndan sonra ise Kasaba Doktoru (1948), Íspanyol Kasabası (1951) ve gönüllü hekim Albert Schweitzer'i konu edindiği Merhametli Adam (1954) adlı foto-röportajları Life'ta yayımlanmıştır.

Savaş fotoğrafçılığından, dönemin ünlü kişileriyle yapmış olduğu röportajlara deyin farklı konular üzerinde çalışan Smith'in Magnum için yapmış olduğu röportajlardan birisi de Minamata'dır. Smith'in çekimlerine 1971 y1lında başladığı ve yaklaşık 4 yılda tamamladığı proje; Japonya'nın Minamata Köyü’nde yaşanan çevre felaketiyle ilgilidir. Bu balıkçı kasabasında faaliyet gösteren Chisso Kimya Fabrikası, metil civa atıklarını köyün bulunduğu koya akıtmasıyla büyük çaplı çevre felaketinin yaşanmasına sebep olmuştur. Kimyasal atıkların besin zincirine dahil olmasıyla, insan metabolizmasını etkileyen ve Minamata Hastalığ ad$_{1}$ verilen bu sendrom, köyde yaşayan insanları etkisi altına almıştır. Smith, 1971 yılında Minamata’ya ulaştığında bu hastalıktan etkilenen insanların fazla oluşundan ve bu hastalığa neden olan fabrikanın tazminat ödeme konusundaki isteksizliğinden dolayı etkilenmiştir. "Bu haksızlığın dünyaya duyurulması gerekliydi ve bu doğrultuda bir foto-röportaj için hazırlıklara başlamıştır. Ortamı tanımak ve insanların güvenini kazanmak için en az dört aya ihtiyacı olmuştu” (Yaman, 2019, parag. 6). Hazırlık aşamasından sonra çekimlere başlayan Smith, 4 yıl boyunca fabrika karşıtı yürüyüşler, cenaze törenleri, avlanan balıkçılar, basın toplantıları, bu felaketin insanlar ve doğa üzerindeki fiziksel etkileri ve Minamata'da gündelik yaşantı gibi farklı alanlarda fotoğraflar çekerek uzun soluklu bir proje hazırlamıştır.

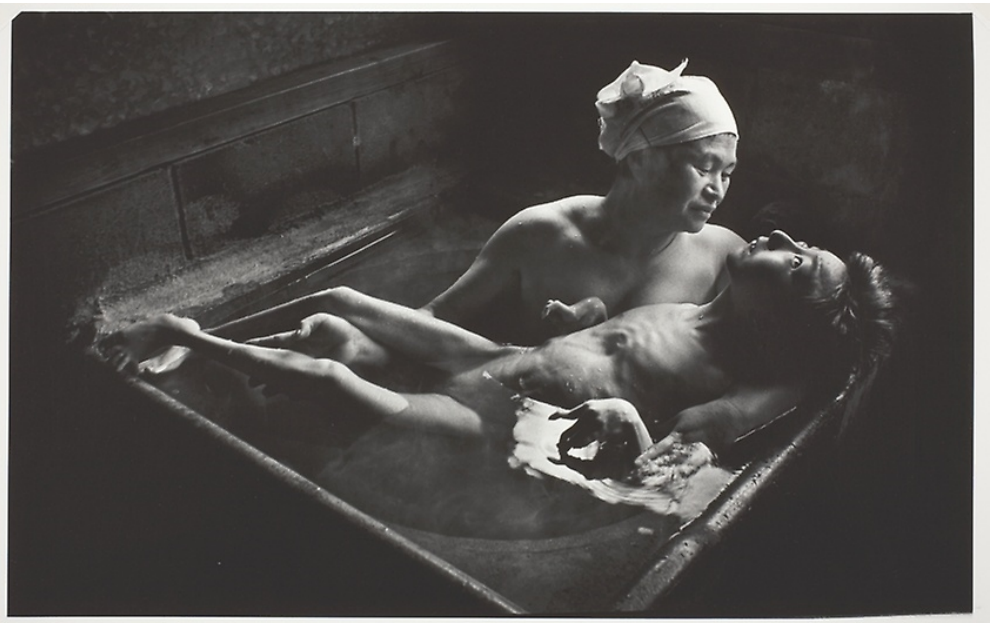

Görsel 9. Eugene Smith, Tomoko Uemura Banyosunda, 1972

Life' ın Haziran 1972 sayısında yayımlanan Minamata projesini oluşturan fotoğraflardan birisi de Tomoko Uemura Banyosunda'dır (Bkz. Görsel 9). Bu fotoğraf incelendiğinde, Minamata hastalığından dolayı doğuştan anomaliye sahip Tomoko'nun annesinin kucağında geleneksel Japon banyosu alırken görülmektedir. Tek kaynaktan gelen doğal 1şık, karanlık bir ortamda bulunan Tomoko ve annesini aydınlatmaktadır. Fotoğraftaki 1şık kullanımı bu yönüyle Rembrandt aydınlatması'nı andırmaktadır. Diğer yandan annenin Tomoko'yu şefkat dolu kavrayışı; Meryem Ana'nın çarmıha gerilmiş İsa'yı kucağında tutarken gösteren Pieta adlı alegoriyle özdeşleşmektedir. Bu foto-röportajin Japon siyasetinde örnek bir olay olduğunu düşünen New York Times eleştirmenleri bu fotoğrafi, Endüstriyel Çağın Pieta'sı olarak adlandırdılar (Holmes, 2009, parag. 3). Bu adlandırmanın kökeninde, bu fotoğrafla dünya çapında dikkatlerin Minamata'daki trajediye toplanmasına neden olmuşu bulunmaktadır. Diğer bir değişle Smith bu çalışmasında, toplumsal içerikli bir konuyu sanat tarihine ait bir esere öykünerek fotoğraflamıştır. Bu yaklaşımın temelinde, teknolojik gelişmeler perspektifinde fotoğrafın teknik sınırlarını aşması bulunmaktadır. Bununla birlikte başta Life dergisi olmak üzere içeriğinde barındırdığı foto-röportajlarla yazarokuyucu ilişkisini kökten değiştiren ve fotojurnalizmi modern çehreye kavuşturarak kamuoyu üzerinde etki yaratır hale gelmesini sağlayan görsel dergiler, 1980'li yıllardan başlayarak düşüşe geçmeye başlamıştır.

Görsel dergilerin gerileme sürecine girmesiyle, foto muhabirler çalışmalarını farklı alanlarda temsil etmeye başlamaktadırlar. Bu olguyu ortaya koyan akademisyen ve fotoğraf kuramcısı Andy Grundberg'e göre: Dergi ve gazetelerde yerini kaybetmeye başlayan fotojurnalizm; 1980'li yılların sonuna doğru müze ve galerilerde düzenlenen retrospektif sergilerle ayrıca akademide düzenlenen sempozyumlarda büyük ilgi uyandırmasıyla eski göz alıcı statüsünü geri kazandığını savunmaktadır. Diğer yandan foto-röportaj kitaplarının yayımlanarak Amerika Birleşik Devletleri'nde çok satanlar listesine girmesi ve Oliver Stone'un bir foto muhabiri konu edinen Salvador (1986) filmini çekmesi gibi nedenlerden dolayı yeni fotojurnalizm'den bahsetmek mümkündür. Grundberg'e (1987) göre,

Fotojurnalizmde; Robert Capa ve W. Eugene Smith gibi koruyucu aziz figürlerinden miras aldıkları gelenekten memnun olmayan, 30'lu ve 40'lı yaşların başında yeni bir jenerasyon fotoğrafçıyla olabildiğince 
taze ve deneysel bir ruh hüküm sürmeye başladı. Fotoğraflarının hem sosyal hem de kişisel türde daha karışık ve sofistike anlamlar taşımasını istiyorlar. Bu amaçla fotoğraflarının temsil ettiği bağlamları kontrol etmek istiyorlar (Parag. 4).

Fotojurnalizmde yaşanan bu değişimin temelinde yazılı basına nazaran daha hızlı bilgi iletilmesini sağlayan televizyon yayıncılığının gelişerek geniş kitlelerce takip edilen bir haber kaynağı haline gelmesi yatmaktadır. Böylelikle Smith ve Capa geleneğindeki vurucu fotoğraf kompozisyonlarını yayınlamaya istekli dergi ve gazete sayısında azalma yaşanarak foto-röportajların hem formunda hem de sunum şekillerinde değişim meydana gelmektedir. Diğer yandan yeni fotojurnalizmin ortaya çıkmasında renkli fotoğrafın yaygınlaşarak sanatsal çalışmalarda kullanılmaya başlaması yatmaktadır.

Kodak, geliştirdiği 35mm renkli filmi 1936 yılında piyasaya sunmuş olsa da klasik fotojuranlizmin siyah-beyaz fotoğrafa olan tutkusu, 1970'lerde yıkılmaya başlanmıştır. "Renkli filmden tamamen farklı bir nedenden ötürü sakınılmıştı: O, reklam çekimlerinde ve amatörler tarafından kullanıldı" (Schwendener, 2010, parag. 3). Renkli fotoğrafa karşı bu bakış açısı, William Eggleston’un (d.1939) özellikle 1970'li yıllarda ürettiği çalışmalarla renkli fotoğrafın meşru bir sanatsal ortam olarak tanınmasıyla değişmeye başlamıştır. Bu gelişmenin etkisinde Larry Burrows (1926-1971) ve John Olson Vietnam Savaşı'nı Kodakchrome'un sahip olduğu zengin renk skalasıyla fotoğraflamıştır. Bununla birlikte Grundberg'in bahsetmiş olduğu 1980'lerin yeni nesil fotojurnalistlerden Susan Meiselas, 1981 tarihinde kitap olarak yayınlanan Nikaragua adlı foto-röportajı da geniş renk skalasına sahip fotoğraflardan oluşmaktadır.

Magnum fotoğrafçısı Meiselas'ın 1979 yılında Nikaragua'da yaşanan Sandinista Devrimi'nin önce ve sonrasını konu edinen bu foto-röportajında yer alan çalışmalardan birisi de Diriamba'da çekmiş olduğu Pazar (Bkz. Fotoğraf 9) adlı çalışmadır. Meiselas'ın Pazar adlı çalışması incelendiğinde ön planda elinde plastik üç oyuncak tutan pazarcının üst açıdan fotoğraflandığı gözlemlenmektedir. Ayrıca farklı renklerdeki asker figürlü oyuncakların perspektifinden, yere çömelmiş bir çocuk görülmektedir. Arka planında pazarda gündelik yaşantısına devam eden insanların gözüktüğü çocuk, sırtında yük dolu çuval tutmaktadır. Diğer bir deyişle üst açıyla fotoğraflanan çocuk, asker şeklindeki oyuncakların bir çeşit baskınlığı altında ezilmektedir. Çocuğun oyuncaklara sert bakışı da bu olguyu kuvvetlendirmektedir. Fotoğrafta çocuk ve asker oyuncaklar arasındaki bu ilişki, Nikaragua'nın yakın tarihine bir göndermedir: Sandinista Devrimi öncesinde Somaza Ailesi ülkeyi yaklaşık 40 yıl silah zoruyla yönetmiştir. Farklı bir deyişle Pazar adlı çalışmada; içerisinde yan anlamları barındıran sembolik anlatıma başvurularak konuya dair gerçeklik ifade edilmektedir. Diğer yandan Meiselas'ın Nikarugua'sındaki diğer fotoğraflar gibi bu fotoğrafı da doygun ve canlı renk tonlarına sahiptir.

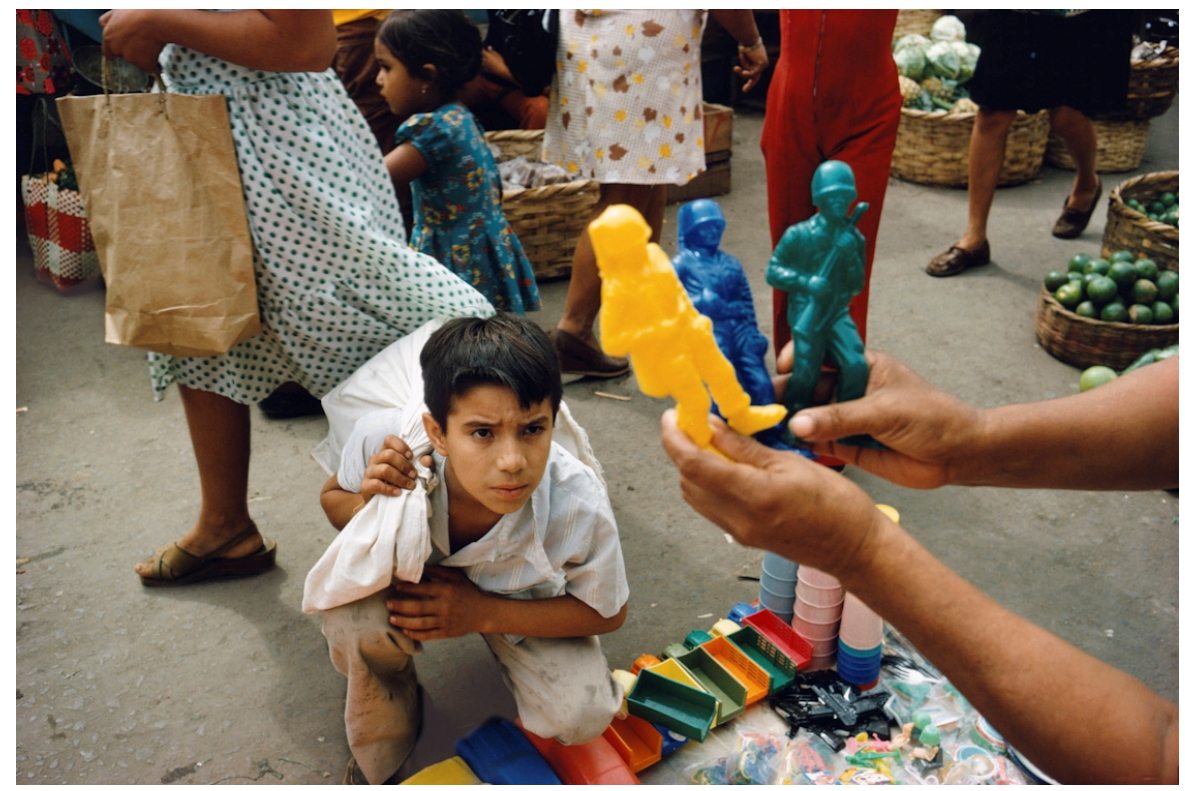

Görsel 10. Susan Meiselas, Pazar, Diriamba, 1979

Meiselas'ın Nikaragua adlı kitabındaki doygun renklere sahip çalışmaları, fotoğraf camiasında ses getirerek, klasik fotojurnalistlerin siyah-beyaz fotoğrafla kurduğu derin bağ aşılmaya başlanmıştır. "Sonuç olarak Meiselas'ın kitabının rahatsız edici bir etkisi oldu. Fotoğraflar, sanatsal çalışmalara özellikle de Modern Sanat Müzesi'nde 5 yıl önce sergilenen William Eggleston'un renkli sanat fotoğraflarına benziyordu" (Grundberg, 1987, parag. 8). Meiselas'ın, çağdaş sanat anlayışı etkisindeki renkli çalışmalarıyla farklı bir boyut kazanan fotojurnalizm, 1980'li yıllardan itibaren yaşanmaya başlanan fotoğraf tekniğindeki dijitalleşmeyle dönüşüme uğramıştır. Fotoğraf tekniğinde yaşanan bu dönüşüm, 1990’lı yıllarda adından bahsedilmeye başlanan ve post- 
fotoğraf olarak adlandırılan dönemin yaşanmasını sağlayarak, bu süreçte üretilen fotojurnalist çalışmaları etkilemektedir.

\subsection{Post-Fotoğrafta Fotojurnalizm}

Amerikalı elektrik mühendisi Steve Sasson’un 1975 yılında geliştirdiği ilk dijital fotoğraf makinesi, 1şığa duyarlı kimyasallardan faydalanan fotoğraf tekniğinde yeni bir çı̆̆ır açılmasına neden olmuştur. Bu gelişmenin ardından Sony, 1981 yılında Mavica adlı dijital fotoğraf makinesini piyasaya sunmuştur. Düşük çözünürlüğe sahip Mavica, az sayıda fotoğraf çekilmesine olanak tanıması ve yüksek fiyatından dolayı piyasada talep görmemiştir. "Fakat hareketin ivme kazanması şu an bildiğimiz haliyle, arka yüzünde LCD ekran olan fotoğraf makinelerinin 1990'larda ortaya çıkmasıyla gerçekleşti. Fotoğraf makinesi piyasasındaki patlama, modellerin artmasıyla 1998 yılına doğru yaşandı" (Bajac, 2011, s. 99). Bununla birlikte bilgisayar ve internetin yaygınlaşmasıyla 2000'li yılların başından itibaren dijital fotoğraf makineleri, analog karşısında kendini kabul ettirmeye başlamıştır. Gümüş nitrat tuzlarının yerini nano teknolojiyle üretilmiş ışığa duyarlı elektronik birimlere bıraktığı bu dönemde fotoğraf, sayısallaşarak varlığını bilgisayar ortamında sürdüren bir medya haline gelmektedir. "Dijital fotoğraf, analogdan farklı olarak, bir bütün olarak gösterilecek sürekli tonların ilk durağan kaydına ya da karanlık odada didiklenmeye değil, bağlantı kurabilen, aktarabilen, yeniden bağlamlanabilen ve üretilen görünenin kesitli ve her türlü şekle girebilir kayıtlarını yaratmaya dayanır” (Ritchin, 2012, s. 139). Bu değişim amatör ve profesyonel fotoğraf geleneğinde önemli bir değişikliğin de yaşanmasına sebep olmaktadır. Karanlık oda sürecine tabii tutulmaksızın çekilen dijital fotoğraf, internet vasıtasıyla anlık olarak iletilebilir ya da paylaşılabilir hale gelmektedir. Özellikle foto muhabirler için önemli bir avantaj sağlayan bu hız, fotoğrafın televizyon karşısındaki dezavantajını da ortadan kaldırmaktadır.

Dijital devrim, fotoğrafın doğasını sadece teknik anlamda değiştirmekle sınırlı kalmamaktadır: "Dijitalin ortaya çıkması ile doğrulama gereksinimi prensibinden ayrılan ve otoritesini kaybeden fotoğrafçılık, günümüzde gerçeklikle olan ilişkisini yeniden gözden geçirmek durumunda kalmıştır" (Bajac, 2011, s. 115). Bununla birlikte Sağlamtimur'a (2016) göre, Dünyada var olan bir şeyleri doğrulamak gibi bir karakteristiğe sahip olan fotoğrafçılığın, artık bu özelliği yansıtmadığı alanına post-fotoğrafçılık denmektedir (s. 652). Diğer bir deyişle dijitalleşmeyle fotoğraf, sınırlarının yıkılarak genişlediği ve kendine özgü estetik anlayışın geliştiği yeni bir döneme girmektedir.

Fotoğrafta dijitalleşmenin başladığı 1990'lı yıllarda adından bahsedilmeye başlanan post-fotoğrafçılık, "temelinde bilgisayar, internet, fotoğrafçılık, sanat ve teknolojinin bulunduğu, fotoğrafçılığ yapısal olarak değiştiren bir yaklaşım olarak değerlendirilmiştir (Sağlamtimur, 2016, s. 649). İlk örneklerine 1980'li yılların başlarında Nancy Burson ve Jeffrey Shaw gibi fotoğraf sanatçılarının çalışmalarında rastlanan post-fotoğraf, fotoğrafin nesnel gerçeklikle kurduğu bağı derinden etkilemektedir. Shore’a (2014) göre,

Bu fikir, fotoğrafçılığın her şeyden önce bir tanıklık ortamı olduğu, dünyaya kendiliğinden etkileyici bir pencere olduğu ve öncelikle 'gerçeklik' olarak adlandırdığımız şeyi kaydetme ile ilgili olduğu konusunda 1srar ediyor. 21. yüzyılın entelektüel ve teknolojik ortamında, daha önceki jenerasyon fotoğrafçıların ekmeğine yağ süren nesnel gerçeklik kavramı, sürekli olarak test edilmektedir; gerçek ve kurgu arasındaki ayrımı oluşturan sınır durmadan bulanıklaşmaktadır. Genel olarak, bugünlerde fotoğrafçılıktan beklemeniz gereken son şey nesnel gerçeklikte (s. 8).

Post-fotoğrafik dönemde fotoğrafta gerçek ve kurgu arasındaki ayrımın gittikçe bulanık hale gelmesi, özellikle kendisini sanatsal çalışmalarda göstermektedir. Bununla birlikte ilk olarak 1980'li yıllarda sanatsal çalışmalarda post-fotoğrafik örneklere rastlanmasına karşın, bu yeni dönemin estetik yaklaşımlarının fotojurnalizmi etkilemesi 2010 'lı yıllarda gerçekleşmektedir. Diğer yandan post-fotoğrafın gerçek ve kurgu arasındaki keskin sınırları bulanıklaştıran estetik yaklaşımı nesnel gerçekliği merkezine alan fotojurnalizmde tartışmalara yol açmaktadır. Bu tartışmalara öncülük eden fotoğrafçı, Micheal Wolf’tur (1954-2019).

Almanya doğumlu Wolf, Stern dergisi için foto muhabirlik yaparak başladığı kariyerini, 8 yıl çalıştıktan sonra noktalayarak kişisel çalışmalarına odaklanmıştır. Bu dönem içerisinde Google Sokak Görünümü'nden faydalanarak ürettiği serilerden birisi de Sokak Görünümleri adlı projesinin içerisinde yer alan Bir Dizi Talihsiz Olay'dır. "Foto muhabir (ya da sanat fotoğrafçısına dönüşen) Micheal Wolf, bilgisayar ekranından çektiği Google Sokak Görünümü fotoğraflarından oluşan Bir Dizi Talihsiz Olay adlı serisiyle 2011 Dünya Basın Fotoğrafı ödüllerinde tartışmalı bir şekilde onur ödülü kazandı" (Shore, 2014, s. 8). Sanatçının sanal gerçeklik içerisinde dünyanın çeşitli şehirlerini bilgisayar başında gezmesine olanak tanıyan Google Sokak Görünümü'nden faydalanarak oluşturduğu bu serisinde yer alan çalışmalardan birisi de Araba Yangını'dır (Bkz. Görsel 11). 


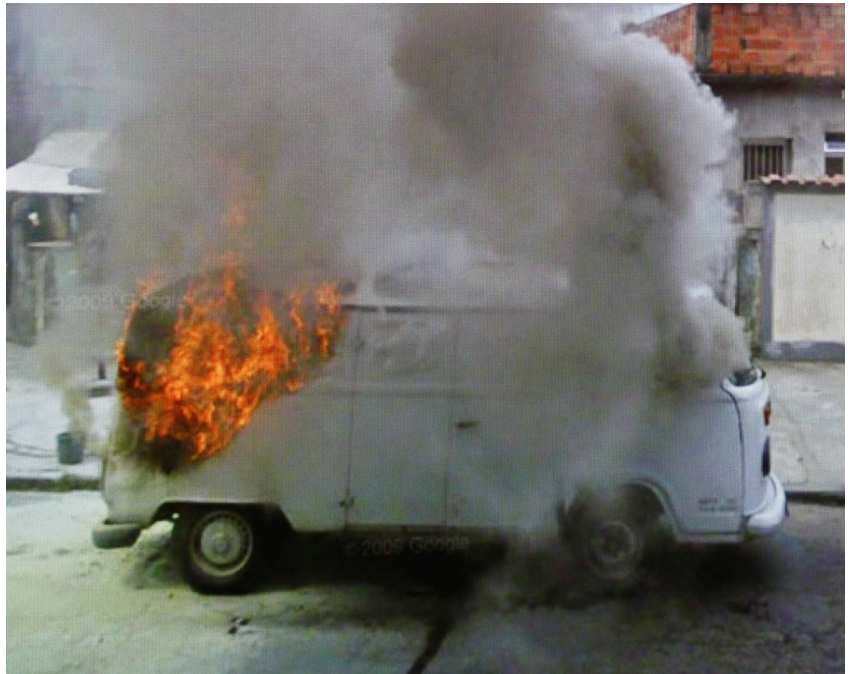

Görsel 11. Micheal Wolf, Araba Yangını, 2011

Bu çalışma; haber niteliği taşıyan bir olayı yani yanmakta olan bir minibüsü konu edinmektedir. Fotojurnalist niteliğe sahip bu çalışmada asıl odaklanılması gereken nokta ise fotoğrafın teknik ve biçimsel özellikleridir. İlk bakışta fotoğrafta büyük ve ızgaralı pikseler dikkat çekmektedir. Piksellerin bu yapısı Wolf'un fotoğrafı, Google Sokak Görünümü'nde karşılaştığı görüntüleri bilgisayar ekranında çekmesinden kaynaklanmaktadır. Diğer yandan çalışmanın konusu olan gerçek olay, Google Sokak Görünümü ekibi tarafından başka bir zaman diliminde çekilmiştir. Böylelikle, basın fotoğrafçılığı açısından prestije sahip bir kurum tarafından onur ödülü kazanan projesi içerisinde yer alan bu çalışmasıyla Wolf, nesnel ve fiziksel gerçekliğe dayalı fotojurnalist yaklaşımı sanal gerçeklikte temsil edilen mekân ve olaylara taşımaktadır. Bu yaklaşım dijital teknolojiyle fotoğrafta yaşanan biçimsel ve içeriksel değişimin, fotojurnalizmdeki karşılığıdır. Post-fotojurnalizm olarak adlandırılan bu yaklaşım, fotojurnalizmin gerçeklikle kurduğu bağın farklı tekniklerle sorgulanmasına yol açmaktadır. Bu tekniklerden biri de genel görüşler çerçevesinde fotojurnalizmin etik değerlerine aykırı kabul edilen dijital manipülasyondur.

Fotoğrafın doğası; her ne kadar nesnel gerçekliliğe dayalı olsa da teknik müdahalelerle manipülasyona açıtır. Dijital teknolojiyle sayısal tabanlı programlar bu teknik müdahaleleri, analoğa kıyasla daha mükemmel hale getirmektedir. Dijital manipülasyonun mükemmeliyetçi biçimi, gerçek olanla manipüle edilmiş olan arasındaki ayrımı zorlaştırmaktadır. "Teknolojik gelişmeler içerisinde özellikle dijital fotoğrafçılık teknolojilerinin fotoğraf sanatına önemli bir yer teşkil etmesiyle, fotoğrafın dış dünyanın gerçekliğini yansıtması inancı dönüşüme uğrar, aslında var olmayan yapay bir dünyadan hareket edilerek görüntü üretildiği ve gerçeğe bir son verilerek, gerçekten daha gerçek oluşturulduğu fikri yaygınlık kazanır" (Sağlamtimur, 2011, s. 163). Bununla birlikte dijital manipülasyona daha çok sanatsal çalışmalarda yer verilse de post-fotoğrafik dönemle birlikte fotojurnalist çalışmalarda da başvurulan bir yöntemdir.

Yang Yi, Çin'de milyonlarca insanın hayatını etkileyen bir trajediyi dijital manipülasyondan faydalanarak anlatma yoluna gitmektedir. Yi'nin Kökünden Kopartmak adını verdiği bu proje; Çin hükümetinin, ülkenin enerji üretimini artırmak amacıyla Yangtze Nehri'nde yaptığı Üç Dar Geçit Barajı’yla ilgilidir. Bu büyük mühendislik ürünü, nehir boyunca onlarca kasaba ve şehri sular altında bırakarak, milyonlarca insanı doğup büyüdüğü topraklardan taşınmasına sebep olmuştur. Yi, bu trajedi gerçekleşmeden önce Kaixian Eyaleti'nde yaşayanları deniz gözlüğüyle fotoğraflamaktadır. Bu proje içerisinde yer alan Kökünden Kopartmak - 19 (Bkz. Görsel 12) çalışmada da deniz gözlüğü takmış bir sokak satıcısı gözükmektedir. Arka planda Kaixian'ın siluetinin gözüktüğü bu fotoğraf, nostaljik bir etki yaratmak amacıyla sepya tonlardadır: "Memleketi Kaixian'a yaklaşmakta olan sel baskısından ilham alan Yang Yi’nin katkısı Kökünden Kopartmak projesi, belirgin bir şekilde nostaljik ve hatta başka bir dünyaya ait kaliteye sahip" (Shore, 2014, s. 234). Diğer yandan çalışmada yer alan özne, şnorkelinden hava kabarcığı çıkartmakta ve fotoğrafın özellikle alt kısmında da dalga yansımaları görülmektedir. Yi, kullandığı bu dijital efektlerle fotoğrafa su altında çekilmiş havası vermektedir. Sanatçı bunun için henüz sular altında kalmamış Kaixian'da çekmiş olduğu fotoğrafları daha önce bir su tankında çektiği hava baloncukları ve su yansımalarını dijital manipülasyondan faydalanarak birleştirmektedir. Yi’nin klasik fotojurnalist yaklaşımların aksine fotomontajla oluşturduğu çalışma, nesnel gerçeklikten ziyade öznel bir gerçeklik barındırmaktadır. Diğer yandan bu çalışmada her ne kadar dijital manipülasyona başvurulsa da Üç Dar Geçit Barajı'nın yol açacağı toplumsal etkiler izleyiciye aktarılmaktadır. 


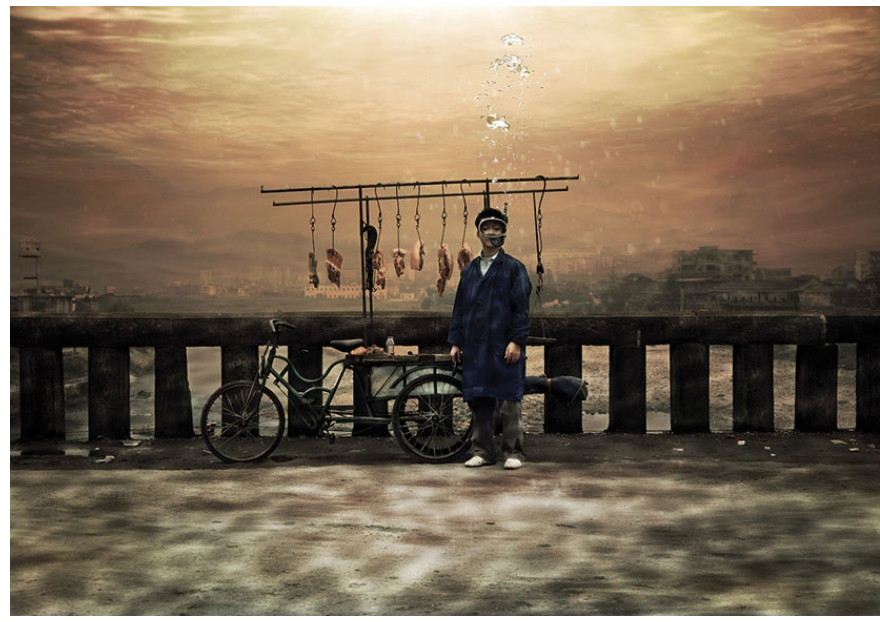

Görsel 12. Yang Yi, Kökünden Kopartmak - 19, 2007

Üretmiş olduğu çalışmalarla post-fotojurnalizmle ilişkilendirilen diğer bir fotoğrafçı da Cristina De Middel'dir. Middel, 2011'de çekimlerine başladığı Afronotlar (The Afronauts) adlı projesinin konusunu; 1960'lı yıllarda Afrika ülkesi Zambiya'nın uzay araştırmaları oluşturmaktadır. Başta ABD'nin 1940'lı yıllardan başlayarak 60'lı yıllara uzanan ABD'nin garip deneylerine odaklanan Middel, tarihteki en çılgın denemelerden birisinin Zambia'nın uzay programı olduğunu keşfeder. Zambiya'da 1960'lı yıllarda fen bilgisi öğretmeni Edward Makuka Nkoloso'nun (1919-1989) başlattığı resmi olamayan uzay programı yarıda kalmıştır. Uzay programı hakkında herhangi bir görüntünün olmadığını fark eden Middle bu konu hakkında fotoğraf projesi oluşturmaya karar verir. Fotoğraf çekimlerinin Alicante (İspanya), Mayorka, İtalya ve ABD gibi yerlerde gerçekleştiği projede, Afrika modasını yansıtacak sahte astronot kıyafetleri giyen farklı özneler modellik yapmaktadır. Bununla birlikte proje hakkında Middle şunları söylemektedir:

Afronotlar aynı zamanda Afrika'ya farklı bir bakış açısı kazandırdı. Afrika'nın imajı, klasik medyanın kıtaya yaklaşması nedeniyle gerçekten zarar görmüştür. Afrika, sömürgeciliğin korkunç bir pazarlama kampanyasının kurbanıdır. Afrika hakkında iyi bir haber yok. İşte bu yüzden Afronautlar gibi bir hikâye çok çarpıcı, çünkü Afrikalıların hayalleri hakkında konuşuyor (Shore, 2014, s. 242).

Middle'ın gerçek ve kurgusal arasında olan Afronotlar projesine ait fotoğraflarından birisi de Iko Iko'dur (Bkz. Görsel 13). Bu çalışma incelendiği takdirde kare formatta olduğu ve eski fotoğraflara atıfta bulunacak şekilde kenar kısımlarının yumuşak kenarlı olduğu gözlemlenmektedir. Renkli çekilmiş bu fotoğrafta, geleneksel Afrika kıyafetleri içerisinde başında astronot başlığı taşıyan bir özne bulunmaktadır. Çekimlerinin Afrika ülkesi dışında bir yerde 2011 yılında gerçekleştirilen Iko Iko, bu yönleriyle, 1960'lı yıllardaki Zambiya'nın gayri resmi uzay programını kurgusal bir gerçeklikte temsil etmektedir. Middel konu hakkında: "Foto muhabirliğin tanımına geri dönerseniz, tamamen imajlarla bir hikâye anlatmakla ilgili olduğu görürüz ve bu durumda 1960'larda gerçekleşen bir hikâye anlatıyorum. Konu hakkında görüntü yoktu bu yüzden bu görüntüleri oluşturmak zorunda kaldım" (Shore, 2014, s. 242) demektedir. Diğer bir deyişle Middel, her ne kadar geçmişe ait bir olayı kurgulayarak yeniden canlandırmış olsa da farklı bir üslupla hikâyeyi anlatma yoluna gitmektedir.

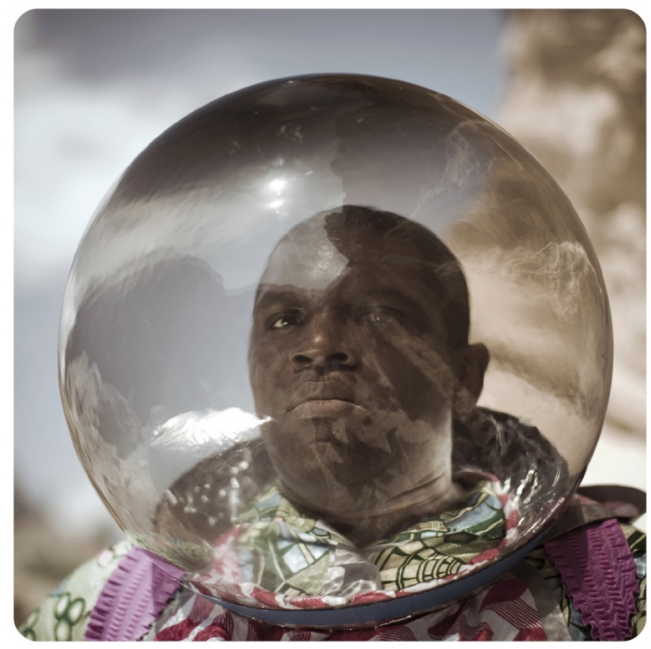

Görsel 13. Cristina De Middel, Iko Iko, 2011 
21. yüzyılın başlarında dijital dönüşüm etkisindeki fotojurnalizm içerisinde geliştirilen gerçekliğin temsili; fotoğrafın gerçeklik ve kurgusal arasındaki keskin sınırın erimesiyle ortaya çıkan yaklaşımlardır. Diğer yandan post-fotojurnalizm adı verilen bu dönem içerisinde; Martina Bacigalupo Gulu Gerçek Sanat Stüdyosu adlı serisinde, fotoğraf stüdyosundan edindiği buluntu fotoğraf'lardan Gulu toplumuna sosyolojik farklı bir bakış açısı kazandırmaktadır. Bununla birlikte Richard Mosse ise kızılötesi film kullanarak Kongo'daki siyasi çalkantıları fotoğraflamıştır. Diğer bir deyişle Wolf, Yi ve Middel'de olduğu gibi post-fotojurnalizm içerisinde çalışmalar üreten Bacigalupo ve Mosse de kullandıkları farklı fotoğrafik tekniklerle, ifade biçimlerine getirdikleri yenilikler bağlamında fotojurnalizm kavramının yeniden şekillenmesini sağlamaktadırlar.

\section{Sonuc}

Gerçekliği olduğu gibi yansıtma özelliğiyle diğer imaj üretim yöntemlerinden ayrılan fotoğraf, icat olmasından itibaren toplumsal olayların belgelenmesi için kullanılan bir araçtır. Fotoğrafın icat olduğu dönemde kullanılan dagerotip ve 1slak kolodyum gibi tekniklerin yetersizlikleri, fotoğrafçıların toplumsal olayları belgelerken konulara olan yaklaşımlarını sınırlandırmaktadır. Bu olguya örnek olarak; Fransa'da 1848 yılındaki işçi ayaklanmalarını dagerotiple belgeleyen Eugene Thibault'un General Lamoricière'nin Birliklerinin Saldırısından Sonra Rue SaintMaur-Popincourt'daki Barikat adlı çalışması incelendiğinde, bu teknik yetersizlikler sonucu konu ve detaylara uzak kalındığı saptanmaktadır. Diğer yandan O’Sullivan'ın, Amerika İç Savaşı'nda 1slak kolodyum tekniğiyle ürettiği Ölümün Hasatı adlı çalışmasında, olayın kendisinden ziyade sonuçlarına odaklanılarak somut bir yaklaşım geliştirildiği gözlemlenmektedir. Bu olgular, fotojurnalizmin başlangıç evresindeki fotoğrafçıların toplumsal olayların temsil ettiği gerçekliği aktarmak için kullandıkları yaklaşımların, ilk fotoğrafik imaj üretim tekniklerinin sınırlılıklarıyla şekillendiğini göstermektedir. Diğer yandan bu dönemdeki basın-yayın teknolojilerindeki yetersizlik, fotoğrafin gazete ve dergilerde yayınlanmasına uygun değildir. Bu teknik sınırlılıklar, 19. yüzyılın sonlarında ve 20. yüzyılın başlarında yaşanan teknik gelişmelerle aşılmıştır.

19. yüzyılın sonlarında fotoğrafın gazete ve dergilerde yayınlanabilir hale gelmesi ve 20. yüzyılın başlarında elde taşınabilen $35 \mathrm{~mm}$ fotoğraf makinelerinin geliştirilmesi, fotojurnalizmin önündeki teknik sınırlılıkları ortadan kaldırmıștır. $35 \mathrm{~mm}$ film kullanan fotoğraf makinelerinin hafifliği, fotoğrafçıya yüksek hareket kabiliyeti sağlamaktadır. Diğer yandan bu fotoğraf makinesi; kullandığı rulo filmle peşi sıra onlarca karenin seri şekilde çekilebilmesine ve değiştirilebilir lense sahip olmasıyla da farklı açı ya da uzaklıklardan kadraj yapılmasına olanak tanımaktadır. Dorothea Lange, Leica'nın bu özelliklerinden faydalanarak Göçmen Anne adlı çalışmasında konunun gerçekliğini en kuvvetli şekilde anlatacak kadrajı yakalama firsatı bulmuştur. Diğer yandan fotojurnalizm, fotoğrafta yaşanan bu teknik gelişmeler ve 1930'lu yıllarda Vu, Life ve Picture Post gibi görsel ağırlıklı haber dergilerinin yayınlanmaya başlamasıyla modern şeklini alarak kurumsallaşmaktadır.

Görsel ağırlıklı haber dergileri ve Magnum Fotoğraf Ajansı gibi kurumların bünyesindeki fotoğrafçılar tarafından şekillenen modern fotojurnalizm içerisinde incelenen Henri Cartier-Bresson'un Trafalgar Meydanı adlı çalışmasında; olgunun kendisinden ziyade analize odaklanıldığı gözlemlenmektedir. Ayrıca Eugene Smith'in özdeşleşen Tomoko Uemura Banyosunda adlı çalışmasında sanat tarihinde önemli bir yere sahip Michelangelo'nun Pieta adlı heykeline öykünülmektedir. Diğer bir deyişle teknolojik gelişmeler sonucunda fotoğrafın teknik sınırlarının aşılmasıyla, gerçekliğin temsiline olan yaklaşımlar değişmekte ve farklı üsluplar ortaya çıkmaktadır.

Televizyonun yaygınlaşmasıyla görsel ağırlıklı haber dergilerin gerileme sürecine girdiği 1970'li yıllarda, fotojurnalist çalışmalara olan ihtiyaç azalmaktadır. Buna karşın fotojurnalizm, müze ve galerilerde sergilenen ayrıca akademik çevrelerin ilgisini çeken bir alan haline gelerek yeni bir çehreye kavuşmaktadır. Fotojurnalizmin büründüğü yeni çehre, klasik yaklaşımlardan memnun olmayan yeni nesil fotoğrafçılar tarafından şekillenmektedir. Yeni fotojurnalizm olarak tanımlanan bu yaklaşımın ortaya çıkmasında, amatör fotoğrafçılıkla ilişkilendirilen renkli fotoğrafın meşru bir sanatsal üretim olarak kabul edilmeye başlanarak, klasik fotojurnalizmin siyah-beyaz filme olan saplantılı tutkusunu sona erdirmesi bulunmaktadır. Yeni fotojurnalizm yaklaşımının temsilcilerinden Susan Meiselas, geniş renk yelpazesine sahip renkli filmle belgelediği Nikaragua'da yaşanan siyasi çekişmeleri konu edinen Pazar adlı çalışmasında; yan anlamlar barındıran sembolik anlatıma başvurularak konuya dair gerçekliğin ifade edildiği gözlemlenmektedir. Diğer yandan fotoğraf tekniği, 20. yüzyılın sonlarında dijitalleşmeyle dönüşüme uğramaktadır.

Işığa duyarlı kimyasallar, yerini piksellere bırakmasıyla gerçekleşen dijital devrim; fotoğrafın doğasını teknik anlamda dönüş̧ürdüğü gibi içerik ve biçimini de etkilemektedir. Bu zaman diliminde gerçek ve kurgusal arasındaki ayrımın bulanık hale gelmesiyle post-fotoğrafik dönemden bahsedilmeye başlanmıştır. Bu olgu fotojurnalizmi derinden etkilemektedir: Objektifini fiziksel gerçekliğin dünyasına yönelten foto muhabir artık sanal mekanlardaki olaylara yönelmektedir. Post-fotojurnalizm çerçevesinde ele alınan bu olguya, Micheal Wolf'un Araba Yangını adlı çalışmasında da rastlanmaktadır.

Post-fotojurnalizmde gözlemlenen gerçek ve kurgusal arasındaki ayrım, çalışmalarda dijital manipülasyonun tercih edilmesiyle daha da bulanık hale gelmektedir. Yang Yi Kökünden Kopartmak - 19 adlı çalışmasında; sular 
altında kalacak Kaixian Eyaleti'nin halkını, sular altındaymış gibi göstermek için dijital manipülasyondan faydalanmaktadır. Yi'nin gerçekleşmemiş bir olayı, fotoğrafik dille daha iyi ifade edebilmek için dijital manipülasyondan faydalanması, klasik fotojurnalist yaklaşımın nesnel gerçeklikle kurduğu bağın yıkılmasına örnek niteliğindedir.

Post-fotojurnalizmle ilişkilendirilen diğer bir fotoğrafçı Cristina De Middel ise 2011 yılında çektiği Iko Iko adlı çalışmasında, Zambiya'nın 1960'lı yıllarda gerçekleştirdiği uzay programını yerel Afrika kıyafetleri giyen astronotlarla yeniden canlandırmaktadır. Böylelikle post-fotojurnalizmde, dijital manipülasyonda olduğu gibi geçmişe ait bir olayın yeniden kurgulanmasıyla, fotoğraftaki gerçek ve kurgusal olan arasındaki ayrım bulanıklaşmaktadır. Böylelikle, başlangıcından post-fotoğrafa fotojurnalizmde gerçekliğin temsiline olan ifade yaklaşımlarının, dönemsel olarak fotoğrafta yaşanan teknik gelişme ve dönüşümler etkisi altında şekillendiği gözlemlenmektedir.

Post-fotojurnalizm çerçevesinde gerçek ve kurgusal olan arasındaki ayrımın bulanıklaşması, özellikle klasik fotojurnalizm düşüncesi perspektifinden tartışmalı bir olgu olsa da gerçeklikle olan bağ tam anlamıyla kopmamaktadır. Bunun aksine post-fotojurnalizmde kullanılan ifade biçimleri, fotoğrafa yeni bir dil yetisi kazandırmaktadır. Diğer yandan, bazı durumlarda post-fotojurnalizmde kullanılan dijital manipülasyon tekniklerinin, fotoğrafın gerçeklikle olan ilişkisini tam anlamıyla ortadan kaldırması da mümkündür. Bu durumda, fotojurnalizmin etik değerleri yıkılarak, kamuoyunu yanlış bilgilendirebilen fotoğraflar ortaya çıkabilecektir. Bunun önüne geçmek adına, dijital manipülasyonla üretilen fotojurnalist bir çalışmanın gerçeklikle kurduğu bağ, etik çerçevedeki sınırlılıklarla muhafaza edilmesi gerekmektedir.

\section{Kaynakça}

About Magnum. (t.y.). Erişim adresi: https://www.magnumphotos.com/about-magnum/overview/

Amar, J. P. (2009). Basın fotoğrafçılı̆̆ İ̀stanbul: Kırmızı Yayınları.

Bajac, Q. (2011). Fotoğraftan sonra: Analog fotoğraftan dijital devrime. İstanbul: Yapıkredi Yayınları.

Bazin, A. (1966). Çăgdaş sinemanın sorunları. Ankara: Bilgi Yayın Evi.

Caple, H. (2013). Photojournalism a social semiotic approach. UK: Palgrave Macmillan.

Freund, G. (2006). Fotoğraf ve toplum. İstanbul: Sel Yayınc1lık.

Gordon, R. (2006). Lewis Hine. L. Warren (Ed.), Encyclopedia of 20th century photography (s.697-701) içinde. New York: Routledge.

Grundberg, A. (1987, 12 Nisan). Art; photojournalism lays claim to the realm of esthetic. The New York Times. Erişim adresi: https://www.nytimes.com/1987/04/12/arts/art-photojournalism-lays-claim-to-the-realm-ofesthetics.html?rref=collection/byline/andy-grundberg

Hacking, J. (2015). Fotoğrafin tüm öyküsü. İstanbul: Hayalperest Yayınevi.

Harcup, T. (2014). A dictionary of journalism. Oxford: Oxford Universty.

Henri Cartier-Bresson. (t.y.). Erişim adresi: https://www.phillips.com/artist/10637/henri-cartier-bresson

Holmes, A. (2009, 6 Mayıs). Tomoko Uemura in her bath. Iconicphotos. Erişim adresi: https://iconicphotos. wordpress.com/2009/05/06/tomoko-uemura-in-her-bath/

Kempf, J. (2006). History of photography: Interwar years. L. Warren (Ed.), Encyclopedia of 20th century photography (s. 731-737) içinde. New York: Routledge.

McDonald, S. (2006). Picture post. Lynne Warren (Ed.), Encyclopedia of 20th century Photography içinde (s. 1266-1268). New York: Routledge.

Ok, S. S. (2016). Fotoğraf bellĕginde acının tasviri. İstanbul: Hayalperest Yayınevi.

Pohlad, M. (2006). History of photography: Twentieth-century developments. L. Warren (Ed.), Encyclopedia of 20th Century Photography (s.714-723) içinde. New York: Routledge.

Ritchin, F. (2012). Fotoğraftan sonra. İstanbul: Espas Yayınları.

Sağlamtimur, Z. Ö. (2011). Fotoğrafçıllı tarihinde teknik ve kültürel dönüşümler. İzmir: Ege Yayınları.

Sağlamtimur, Z. Ö. (2016). Post-fotoğrafçılık: Fotoğrafik gerçekliğin sınırlarının aşılması. A. Göztaş (Ed.), İletişimde Post Yazılar (s. 649-673) içinde. Konya: Literatürk Yayınları. 
Schwendener, M. (2010, 6 Ağustos). Tracking the rise of color on film. Erişim adresi: https://www.nytimes.com/ 2010/08/08/nyregion/08artsnj.html

Senf, R. A. (2008). O'Sullivan, Timothy Henry. J. Hannavy (Ed.), Encyclopedia of 19th century photography (s. 1017-1021) içinde. New York: Routledge.

Shore, R. (2014). Post-photography. London: Laurence King Publishing.

Smith, I. H. (2018). Fotoğrafin kısa öyküsü. İstanbul: Hep Kitap.

Stefan Lorant. (t.y.). Erişim adresi: https://www.britannica.com/biography/Stefan-Lorant

Stetler, P. (2015). ABD’de toplumsal belgesel. J. Hacking (Ed.), Fotoğrafin tüm öyküsü (s. 304-311) içinde. İstanbul: Hayalperest Yayınevi.

Stomberg, J. (2006). Life magazine. L. Warren (Ed.), Encyclopedia of 20th century photography (s. 952-955) içinde. New York: Routledge.

Walden, S. (2006). Ethics and photography. L. Warren (Ed.), Encyclopedia of 20th century photography (s. 454457) içinde. New York: Routledge.

Weintraub, M. (2006). Robert Capa. L. Warren (Ed.), Encyclopedia of 20th century photography (s. 236-240) içinde. New York: Routledge.

Yaman, H. (2019, 3 Eylül). Minamata: Bir kentin trajik öyküsü. Erişim adresi: https://gaiadergi.com/minamatabir-kentin-trajik-oykusu/

Yaykın, M. (2010). Sanat, teknoloji, bilim ve fotoğraf. İstanbul: Kalkedon Yayınları.

\section{Görsel Kaynakçası}

Görsel 1. The Illustrated London News. (1842). Hamburg Yangını [Gravür]. Erişim adresi: https://blog.britishnewspaperarchive.co.uk/wp-content/uploads/sites/9/2017/05/Hamburg.png

Görsel 2. Thibault, Eugene. (1848). General Lamoricière'nin Birliklerinin Saldırısından Sonra Rue Saint-MaurPopincourt'daki Barikat [Fotoğraf]. Erişim adresi: https://www.musee-orsay.fr/en/info/gdzoom.html?tx_ damzoom_pi1[showUid]=109366\&tx_damzoom_pi1[zoom] $=1 \& t x \_d a m z o o m \_p i 1[\mathrm{back}]=/ \& \mathrm{cHash}=9 \mathrm{cee} 6 \mathrm{bb}$ $4 \mathrm{e} 3$

Görsel 3-4. Fenton, Roger. (1855). General Bosquet ve Yüzbaşı Dampierre [Fotoğraf]. Erişim adresi: https://www. macleans.ca/culture/arts/a-picture-paints-a-thousand-lies-on-truth-and-war-photography/

Görsel 5. O’Sullivan, Timothy. (1863). Ölümün Hasatı [Fotoğraf]. Erişim adresi: https://www.moma.org/ collection/works/92454

Görsel 6. Lange, Dorothea. (1936). Göçmen Anne, Nipomo, Kaliforniya [Fotoğraf]. Erişim adresi: https://www. history.com/news/how-photography-defined-the-great-depression

Görsel 7. Lange, Dorothea. (1936). Kaliforniya'da Yoksul Bezelye Toplayıcı 1 ve 2 [Fotoğraf]. Erişim adresi: https://cphmag.com/migrant-mother/

Görsel 8. Cartier-Bresson, Henri. (1937). Trafalgar Meydanı [Fotoğraf]. Erişim adresi: https://huxleyparlour.com/ coronation-of-king-george-vi/

Görsel 9. Smith, Eugene. (1972). Tomoko Uemura Banyosunda [Fotoğraf]. Erişim adresi: https://www.artic.edu/ artworks/48238/tomoko-uemura-in-her-bath

Görsel 10. Meiselas, Susan. (1979). Pazar [Fotoğraf]. Eriş̧im adresi: http://www.susanmeiselas.com/latin-america/ nicaragua/\#id=somoza_regime

Görsel 11. Wolf, Micheal. (2011). Araba Yangını [Fotoğraf]. Erişim adresi: http://photomichaelwolf.com/wpcontent/uploads/car_fire.jpg

Görsel 12. Yi, Yang. (2007). Kökünden Kopartmak, 19 [Fotoğraf]. Erişim adresi: http://www.galeriedix9.com/ en/expositions/presentationarchive/24/uprooted\#oeuv-19

Görsel 13. De Middel, Cristina. (2011). Iko Iko [Fotoğraf]. Erişim adresi: https://www.rencontres-arles.com/files/ media_file_3419.jpg 